\title{
Dynamic Cause of Marginal Lithospheric Thinning and Implications for Craton Destruction: A Comparison of the North China, Superior and Yilgarn Cratons
}

\begin{tabular}{|r|l|}
\hline Journal: & Canadian Journal of Earth Sciences \\
\hline Manuscript ID & cjes-2015-0110.R1 \\
\hline Manuscript Type: & Article \\
\hline Date Submitted by the Author: & O2-Sep-2015 \\
\hline Kist of Authors: & $\begin{array}{l}\text { Wang, Xu; China University of Geosciences, Institute of Geophysics and } \\
\text { Geomatics } \\
\text { Zhu, Peimin; China University of Geosciences, Institute of Geophysics and } \\
\text { Geomatics } \\
\text { Kusky, Timothy; China University of Geosciences, Wuhan, State Key Lab } \\
\text { for Geological Processes and Mineral Resources } \\
\text { Zhao, Na; China University of Geosciences, Institute of Geophysics and } \\
\text { Geomatics } \\
\text { Li, Xiaoyong; China University of Geosciences, Institute of Geophysics and } \\
\text { Geomatics } \\
\text { Wang, Zhensheng; China University of Geosciences, Wuhan, State Key Lab } \\
\text { for Geological Processes and Mineral Resources }\end{array}$ \\
\hline Keyword: & \begin{tabular}{l} 
North China craton, Superior craton, Yilgarn craton, craton destruction \\
\hline
\end{tabular} \\
\hline
\end{tabular}

\section{SCHOLARONE \\ Manuscripts}




\section{Dynamic Cause of Marginal Lithospheric Thinning and Implications}

\section{2 for Craton Destruction: A Comparison of the North China, Superior and Yilgarn Cratons}

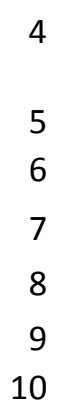
root, with the Yilgarn and Superior cratons, which preserve their roots. We compare the geophysical structure and tectonic histories of these cratons to search for reasons why some cratons lose their roots, while others retain them. Based on the comparison and analysis of geological, geophysical and geochemical data, it is clear that the between plates. However, craton destruction is not always accompanied by lithospheric thinning, except for cratons that suffered subduction and collision from multiple sides. The western block (also known as the Ordos Block) of the NCC, Yilgarn and Superior cratons have not experienced craton destruction; the common ground among them is that they are surrounded by weak zones (e.g., mobile belts or orogens) that sheltered the cratons from deformation, which contributes greatly to the long-term stability of the craton. Subduction polarity controlled the water released by the subducting plate, and if subducting plates dip underneath the craton, they release water which hydroweakens the overlying mantle, and makes it easy for delamination or sub-continental lithospheric mantle (SCLM) erosion to take place in the interior of the craton. Thus, subduction polarity during convergence events is an important element in determing whether a craton retains or loses its root. 
Keywords: North China craton, Superior craton, Yilgarn craton, craton destruction

* Corresponding author, tkusky@gmail.com

\section{Introduction}

Cratons are tectonic units that account for about $50 \%$ of the Earth's land area. Main characteristics of cratons are that they can maintain long-term stability ( $>1 \mathrm{Ga}$ ), and deformation is extremely weak after their formation and stabilization. They formed in the Precambrian and are by definition more than 1.0 Ga old (Windley 1995), with most forming in the Archean (>2.5 Ga) and are composed of ancient continental crust and lower sub-continental lithospheric mantle (SCLM, or root). Due to the low heat flow values, low density, high seismic velocity, thick and refractory lithosphere (Morgan 1984; Shapiro et al. 1999; Sengör 1999; James et al. 2001), cratons have the ability to record a long geological history and avoid destruction in later geological events. However, studies about the Archean eastern North China craton (NCC; Fig.1B) indicate that it lost its root in the Mesozoic (Menzies 1993; Griffin et al. 1998; Zhang et al. 2002, 2003; Kusky et al. 2007a, b, 2014b; Zhu et al. 2012). Research on mantle xenoliths contained in diamond-bearing kimberlites combined with geophysical data show that the thickness of the lithosphere of the eastern NCC changed from 180-200 km in the Paleozoic to 80-100 km at present (Ma et al. 1984; $\mathrm{Ma}$ and Wu 1987; Yuan 1996; Menzies 1993; Griffin et al. 1998; Yang 2003; Kusky et al. 2007a; Li et al. 2009; Zhu and Zheng 2009). Furthermore, the nature of the lithosphere and the thermal state (Wu et al. 2008a) changed greatly at the same time, which reflects that the eastern NCC has been decratonized (Zhu et al. 2012), manifest as large-scale tectonic deformation and magmatic activity. Thus, stable cratons can become active undter://mc06, manuscriptcentral.com/cjesspubs can become thinner, and its 
composition can also be altered or the SCLM can be replaced with new fertile mantle (Gao et al. 2002; Zhai et al. 2007; Zheng et al. 2007).

In recent years much research has been done on searching for the dynamic cause of cratonic lithospheric thinning (e.g., Zhao et al. 2004; Wilde et al. 2003; Gao et al. 2002, 2009; Xu 2001, 2007; Deng et al. 2004, 2007; Zhu et al. 2012; Miller et al. 2012; Kusky et al. 2007a, 2014b), with much work focused on the destruction of the NCC. Continental-continental collision is considered to be able to cause lithospheric thinning as this process can cause lithospheric or at least crustal thickening (Dewey and Burke 1973), which leads to gravitational instability and therefore provides advantages for the occurrence of delamination, and finally gives rise to the lithospheric thinning ( $\mathrm{Li}$ 1994, 1998; Gao et al. 2002, 2009; Zhang et al. 2002, 2003; Wu et al. 2003, 2006). Most scholars also suggested that subduction of oceanic plates played a key role in the destruction of the NCC. The subduction, flattening, and roll-back of the Izanagi (sometimes referred to as the Paleo-Pacific) and Pacific plates is suggested by many to be the primary tectonic factor that led to the destruction (Griffin et al. 1998; Wu et al. 2003; Niu 2005; Kusky et al. 2014b). In addition, there are also some scholars who regard mantle plumes as the cause of craton destruction (Flower et al. 1998; Zhao et al. 2004; Wilde et al. 2003). To clearly understand the problem, it is necessary to compare the unique tectonic evolution of the NCC to the other representative Archean cratons, and conduct a comprehensive comparison. Among the Archean cratons, we selected the Yilgarn and Superior cratons which both preserve thick roots and are in a stable condition, to search for what in their tectonic history is different that may have led to the destruction of one craton, and the preservation of others. 
America, respectively. These two cratons still maintain a relatively stable state (Myers 1993;

Kendall et al. 2002; Graham et al. 2004; Frederiksen et al. 2007; Huston et al. 2012) with no significant seismic activity, magmatic activity and little internal deformation. All three cratons formed in the Archean, but experienced different tectonic events since then, and now exhibit different states. Therefore, a comparison between these two different types of cratons can provide information about craton destruction and lithospheric preservation.

\section{North China Craton}

\subsection{Geologic setting} the eastern and western blocks by the Central Orogenic Belt (Fig.1B; Griffin et al. 1998; Menzies and Xu 1998; Kusky and Li 2003; Zhao et al. 2005; Kusky et al. 2007a; Wu et al. 2008a; Santosh et al. 2010; Kusky 2011; Zhu et al. 2011, 2012). It is bounded by the Central China orogen (including the Qinling-Dabie belts) to the southwest, and the Central Asian Orogenic Belt to the north (Fig.1A; Davis et al. 2002; Windley et al. 2007; Kusky et al. 2007a), the eastern border is the Sulu orogen and its extensions in Korea along the Ogesheon belt (Oh and Kusky 2007). Most parts of the eastern NCC are dominated by lowlands with altitudes generally lower than $200 \mathrm{~m}$. In contrast, the central and western NCC are characterized by high altitudes ranging from 500-3500 m (Jiang et al. 2013). Cenozoic rifts surround the Ordos Block (Fig.1B), to the east is Shanxi-Shaanxi Rift (SSR), and to the north is the Yinchuan-Hetao Rift (YHR, Fig.1B; Zhang et al. 1998). 
The oldest rocks in the NCC were formed at about $\sim 3.8 \mathrm{Ga}$, and crop out at Anshan (Liu et al.

1992; Wu et al. 2008b) and Xinyang (Fig.1B; Zheng et al. 2004). The dominant crustal age ranges from $\sim 2.5 \mathrm{Ga}$ to $\sim 3.0 \mathrm{Ga}$, with peaks in ages between $\sim 2.7-2.9 \mathrm{Ga}$ (Kusky et al. 2007c). The eastern NCC mainly contains early to late Archean high and low grade tonalitic, trondhjemitic and granodioritic (TTG) gneisses (Zhao et al. 2001). The western NCC is characterized by late Archean to Paleoproterozoic metasedimentary belts which unconformably overlie the Archean basement (Kröner et al. 2005). The Central Orogenic Belt includes a series of $2.5-2.7 \mathrm{Ga}$ amphibolite to granulite facies terrains and $\sim 2.5$ Ga greenschist facies granite-greenstone terrains (Kusky 2011; Kusky and Zhai 2012). This orogen contains a circa 2.5 Ga suture, where an arc is interpreted to have collided with the Eastern block, a younger suture $(\sim 2.4-2.1 \mathrm{Ga})$ on the western side of the belt where the Western block collided with the Central Orogenic Belt (Kusky et al. 2007a,c; Kusky and Li 2003; J.P. Wang et al. 2013; Deng et al. 2013). The whole craton then experienced a high-grade tectonothermal event at $\sim 1.9-1.85 \mathrm{Ga}$, related to when the NCC joined the Columbia supercontinent along its northern margin (Kusky et al. 2007c; Kusky and Santosh 2009; Peng et al. 2014).

Studies of mantle xenoliths contained in the diamond-bearing Ordovician kimberlites located in the eastern NCC (Mengyin and Fuxian, Fig.1B) show that the lithospheric mantle beneath the NCC had a thickness of about $200 \mathrm{~km}$ in the Paleozoic ( $470 \mathrm{Ma})$ and maintained typical natures of the Archean cratonic lithosphere mantle (Griffin et al. 1992, 1998; Menzies et al. 1993; Menzies and Xu 1998; Wu et al. 2006). However, research on mantle-derived inclusions in Cenozoic basalts indicates that the lithospheric thickness was reduced to about $80-120 \mathrm{~km}$ by then (Fan and Menzies 1992; Wu et al. 2003; Zheng et al. 2006), suggesting that more than $100 \mathrm{~km}$ of lithospheric thinning

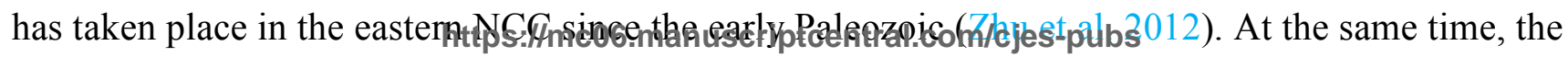


nature of the SCLM changed essentially and is now characterized by high heat flow, abundant large

earthquakes and significant deformation. The stable properties of the North China craton were lost in the Meszoic (Liu et al. 2001; Zhang et al. 2002), which suggests that the eastern NCC had not only experienced lithospheric thinning but a wholescale destruction of the SCLM (Zhu et al. 2011, 2012). Compared to the eastern NCC, the western block has a lack of magmatic activity, has lower surface heat flow (Hu et al. 2000), a fairly thick crust (Li et al. 2006) and SCLM (Chen 2009). Recently, a series of geophysical data show that the SCLM thinning has also occurred in local parts of the western block (Chen 2009, 2010; Jiang et al. 2013), but the main body still preserves thick SCLM. So the western block has not been destroyed, only experienced local lithospheric thinning or modification (Zhu et al. 2012), and has remained relatively stable.

Since cratonization at 1.8 Ga (Wilde et al. 2002; Zhao et al. 2001, 2005, 2006; Liu et al. 2009; Guo et al. 2005; Zhai et al. 2005; Zhai 2011; Zhao and Zhai 2013), the NCC remained relatively stable with thick Archean SCLM until the early Mesozoic. Because the destruction mainly took place after the Paleozoic, the following section is a review of its tectonic evolution since the Paleozoic (Table 1).

The Qaidam plate subducted beneath the NCC in the early Paleozoic and formed the active southern margin of the NCC (Yin and Nie 1996). The Yangtze craton subducted underneath the NCC in the Permo-Triassic (Li et al. 2004; Hacker et al. 2009), which resulted in exposure of ultra-high pressure rocks in the Dabie Shan and Sulu orogens, and westward extrusion of the southern Tarim-Qaidam block (e.g., Sengör 1985; Hacker et al. 2000; Ratschbacher et al. 2003).

1 The subduction of Yangtze craton may have reached to depths up to $200 \mathrm{~km}$ (Ye et al. 2000; L.

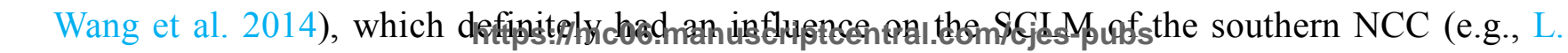


Wang et al. 2010, 2014). The Tan-Lu fault may have initially formed during this convergent event between the Yangtze craton and NCC (Yin and Nie 1993).

\section{Table 1 around here}

After the break-up of the Columbia (Nuna) supercontinent (Rogers and Santosh 2002), the northern margin of the NCC was affected by the evolution of adjacent oceans, namely Panthalassa (Musashino 1990), the predecessor of Paleo-Asian Ocean. The northern part of the NCC was relatively stable from then until the Paleozoic (Kusky and Li 2003; Zhao et al. 2010; Zhang et al. 2011). During the early Paleozoic, the Bainaimiao arc developed along the southern part of Xin-Meng orogen (part of the Central Asian Orogenic Belt, Fig.1B), but during this period, the northern NCC was still stable. From the Paleozoic to early Permian, the Paleo-Asian Ocean to the north of the NCC was open, so there were some active subduction zones which led to the growth of the craton through acceretion and arc magmatism along the northern margin (Yin and Harrison 2001; Davis et al. 1996; Xiao et al. 2003). During the late Paleozoic, the northern margin of the NCC changed into an active Andean style continental margin, and the Paleo-Asian Ocean subducted beneath the NCC, which finally generated the collision between the NCC and the Mongolia block at the end of the Permian (Xiao et al. 2003; Windley et al. 2007). Studies of tectonism and magmatism show that the closure of the Paleo-Asian Ocean affected the NCC (Davis et al. 2001; Xiao et al. 2003; Zhang et al. 2003, 2010, 2011, 2012; S.H. Zhang et al. 2014). The gradual subduction of the Paleo-Asian Ocean and collision of various terranes formed the Central Asian orogenic belt (Robinson et al. 1999; Badarch et al. 2002; Zhang et al. 2003; Xiao et al. 2009a). A series of studies (e.g., Xiao et al. 2003, 2009a, 2012; Windley et al. 2007) show that the evolutionary history of this https://mc06.manuscriptcentral.com/cjes-pubs 
orogenic belt is very complicated, including the closure of the Paleo-Asian Ocean, the subduction of oceanic plates, the collisional event between the NCC and Siberia, and extensive magmatism (Li 2006). A triangular remnant embayment of the Palaeo-Pacific remained in eastern Asia in the mid-late Palaeozoic (Zorin et al. 1998; Zorin 1999) and is known as the Mongol-Okhotsk ocean which finally closed during the late Jurassic-Cretaceous (Tomurtogoo et al. 2005). About nine hundred plutons with late Paleozoic ages intruded in the region of Inner Mongolia located in the northern part of the NCC. Xiao et al. (2003) suggested that these plutons are related to the closure of Paleo-Asian Ocean, and that the ocean closure was associated with south-directed subduction beneath the northern margin of the NCC from 300-250 Ma. This closure combined the north China-Mongolia continent and the Siberia craton. The fact that the intrusions are younger from west to east along the line of the suture suggests that the ocean was closed in a scissor-like movement (Kravchinsky et al. 2002).

From the Paleproterozoic to early Mesozoic, the NCC remained stable with deposition of thick clastic and carbonate rocks. It suffered different degrees of multi-phase deformation, but did not completely lose the basic attribute of a stable craton. In the late Palaeozoic, subduction and collisional events combined with volcanic activity changed the lithospheric thickness of the marginal areas and thermal character of the craton, which provided foundation for craton destruction in the Mesozoic and Cenozoic (Menzies and Xu 1998).

The evolution of the NCC was mainly controlled by the complicated interaction of Eurasian, Indian, Izanagi and Pacific plates during the Mesozoic and Cenozoic. The tectonic evolution during that period can be summarized as convergent events between the NCC and surrounding blocks. The

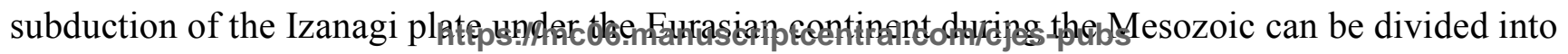



two phases: subduction and contraction during the Jurassic and subduction with extension in the overriding plate (Asia) during the Cretaceous (Wu et al. 2008a). This subduction caused the magmatism, deformation and mantle hydration in the eastern NCC during 200-100 Ma (Niu 2005; Kusky et al. 2007). Significant tectonic regime change of the eastern NCC happened in the late Jurassic to early Cretaceous, when the convergence dominated regime switched to an extensional regime (Menzies and Xu 1998; Kusky et al. 2014a). In the early Tertiary, the collision between India and Eurasia together with the rollback of the Izanagi plate may have caused the deformation of Shanxi-Shaanxi Rift and Yinchuan-Hetao Rift in the western NCC (Xu 2007).

\subsection{Lithospheric structure}

Geophysical methods are widely used in detecting the structure of the crust and mantle, and in recent years there has been a rapid increase of digital broadband seismic data in China. Results from these data show that the thickness of the SCLM of the eastern block of the NCC is about $60-70 \mathrm{~km}$ near the Tan-lu fault and increases to about 90-140 km to the northwest (An and Shi 2006; Huang and Zhao 2006; Huang et al. 2009; Li et al. 2009; Li and van der Hilst 2010; Zhao et al. 2012; Zhu et al. 2012). The eastern NCC can be subdivided into two parts represented and/or covered by the Southern North China Basin and Northern North China Basin (Fig.1B; Huang et al. 2009). The lithosphere of the Southern North China Basin is basically a high velocity lid down to 70-80 km (Fig.2B), and below that, the velocity decreases remarkably. On the other hand, the crust of the Northern North China Basin has a low velocity, and the thickness of the lithosphere is about $130 \mathrm{~km}$

20 (Huang et al. 2009). In general, the eastern NCC exhibits extremely thinned lithosphere that has 
Zheng 2009; Zhu et al. 2012).

Along the northern margin of the NCC, the structure is different from that inside the NCC (Fig.2A). The lithospheric structure beneath the northern margin is dominated by low velocity anomalies, and thin lithosphere of no more than $100 \mathrm{~km}$ was imaged under a large part of the northern margin of the NCC (Tang and Chen 2008; Huang et al. 2009; Jiang et al. 2013). Study of Rayleigh waves in the northern NCC shows that the overall structure of this region is more similar to tectonically active continental regions rather than a stable craton (Tang and Chen 2008). The southern margin of the NCC also shows a relatively low velocity below $80 \mathrm{~km}$ (Fig.2A; Zhao et al. 2012). The eastern parts of the Qinling-Dabie belts are dominated by S-wave velocities of no more than $4.4 \mathrm{~km} / \mathrm{s}$ below $80 \mathrm{~km}$ (Jiang et al. 2013). Geophysical data above show that the lithosphere beneath the marginal areas of the NCC has been thinned.

The strong contrast between the Ordos (Western) Block and the eastern NCC is an obvious feature from the NCC tomographic images (Fig.2). Fig.2 was derived from surface wave study (Jiang et al. 2013) whose dominant resolution is confined to the depth interval of ca. 20-200 km. Checkerboard tests (Jiang et al. 2013) performed to test the resolution were designed with a patch size of $2^{\circ} \times 2^{\circ}$ (ca. $200 \mathrm{~km}$ ) and velocity anomalies of $\pm 5 \%$, results of the checkerboard inversions verified that anomalies revealed by tomographic maps of S-wave velocities are reliable. We can clearly infer from the seismic images that the western NCC has thick lithosphere represented by high-velocity. The Central Orogenic Belt is generally characterized by low-velocity anomalies but exhibits great heterogeneities, which may be the result of multiphase reworking of pre-existing mechanically weak zones since the amalgamation of the craton. High Vp and Vs volumes, along

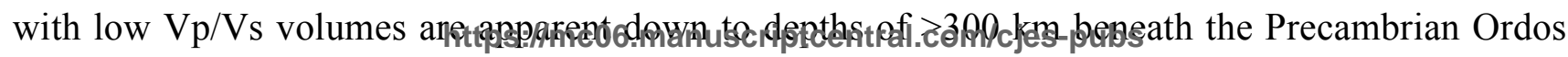


1 Block (X. Wang et al. 2014), indicating that the SCLM is thick with lower temperatures, and has a

2 relatively depleted geochemical composition. However, rifts around the Ordos Block are dominated

3 by strong low-density anomalies (X. Wang et al. 2014; Kusky and Mooney 2015). High-resolution

$4 \quad$ images derived from dense seismic-array data also indicate that the dramatically thinned SCLM is

5 mainly present beneath the Yinchuan-Hetao and Shaanxi-Shanxi rifts, and thick SCLM is preserved

6 beneath the Ordos Block (Chen 2009, 2010; Huang et al. 2009; Bao et al. 2011; Jiang et al. 2013;

7 C.Y. Wang et al. 2014). Geophysical data suggests the coexistence of both thinned SCLM and a

8 preserved cratonic root beneath the central and western NCC (Chen 2009, 2010; Jiang et al. 2013).

\section{Figure 2 around here}

Deep-seated xenolith data record the activities that the lithosphere suffered, which provides the most direct evidence for the structure of the SCLM. Therefore we present xenolith data related to the SCLM thinning beneath the marginal regions of the three cratons in this paper.

Xenoliths derived from Hannuoba which is located near the northern margin of the NCC records ages of $\sim 645 \pm 225 \mathrm{Ma}$ (Yu et al. 2007), 470 Ma and $\sim 315 \mathrm{Ma}$ (Zhang et al. 2012), showing muti-episodic SCLM modification. A zircon age of 470 Ma (Zhang et al. 2011) in the granulites has also been found in Fuxian near the northern margin of the NCC. In addition, a zircon age of 462 Ma contained in xenoliths from the Mesozoic Liaodong basalt close to Fuxian (Zhang et al. 2011) also suggests that the Archean basement of the northern margin of the NCC suffered reworking in the Paleozoic. This is confirmed by seismic profiles across this margin (e.g., Huang et al. 2009). The situation of the southern margin is similar to that of the northern margin. The deep-seated xenoliths from the Mesozoic Jiagou (Fig.1B) dioritic porphyry in the southeastern https://mc06.manuscriptcentral.com/cjes-pubs 
margin of the NCC comprise ages ranging from $\sim 384$ to $\sim 410$ Ma with a weighted mean age of

5

$\sim 393 \pm 7 \mathrm{Ma}$ (Liu et al. 2013). Xenoliths derived from igneous precursors of various ages ( 2.5 Ga, $\sim 2.1 \mathrm{Ga}$ and $\sim 393 \pm 7 \mathrm{Ma}$ ) underwent variable degrees of metamorphic overprinting or reworking at $\sim 2.1 \mathrm{Ga}, \sim 1.8 \mathrm{Ga}, \sim 393 \pm 7 \mathrm{Ma}$ and $\sim 176 \pm 2 \mathrm{Ma}$, respectively (Liu et al. 2013). Xenoliths from the Mesozoic igneous rocks of Xinyang also record age information of 377-263 Ma (Zheng et al. 2008) and $220 \mathrm{Ma}$ (Li et al. 1993).

Heat flow investigations show a cold core is still preserved beneath the western NCC, with low heat flow value of $<50 \mathrm{~mW} / \mathrm{m}^{2}$, indicating a stable state. Heat flow in the Cenozoic rifts around the Ordos block is relatively high, which ranges from 63 to $98 \mathrm{~mW} / \mathrm{m}^{2}$ (Hu et al. 2000). The mean heat flow in the eastern $\mathrm{NCC}$ is $\sim 64 \mathrm{~mW} / \mathrm{m}^{2}$, few boreholes in the ENCC even recorded high heat flow values of $>80 \mathrm{~mW} / \mathrm{m}^{2}$ (He 2015). Huang (2014) collected a large number of heat flow data in the NCC and concluded that the heat flow illustrates a generally eastward increasing trend. The lithosphere inferred from the result of geothermal study is in agreement with the geophysical and geochemistry research as discussed above.

Geological, geophysical and geochemical evidence show that the lithospheric thinning occurred beneath the eastern part, southern and northern margin of the NCC. The Ordos Block in the western part remained relatively stable with local lithospheric thinning of Shanxi-Shaanxi Rift and Yinchuan-Hetao Rift.

\section{Yilgarn Craton}

\subsection{Geologic setting}

The Yilgarn craton (Hhttps://mc06 manuscriptcentral.com/cies-pubs in the southwestern part 
$1 \quad\left(24^{\circ} \mathrm{S}-36^{\circ} \mathrm{S}\right.$, and $\left.114^{\circ} \mathrm{E}-126^{\circ} \mathrm{E}\right)$ of the West Australian shield, covering an area of more than 750,000

$2 \quad \mathrm{~km}^{2}$ (Mole et al. 2012). It is a typical Archean granite-greenstone terrane (Windley 1995; Myers

3 1990, 1995). To the north of the Yilgarn craton, lies another Archean craton named the Pilbara,

4 separated by the Proterozoic Capricorn orogen ( 1.7-2.2 Ga; Fig.3A, Occhipinti et al. 2004). The

5 Proterozoic Pinjarra orogen is situated to the west of the Yilgarn craton, which is overlain by

6 sedimentary rocks of the Perth basin. The southern border of the Yilgarn craton is the Proterozoic

7 Albany-Fraser orogen (Fig.3A). The Yilgarn craton was formed between 2670 and $\sim 2650$ Ma by

8 accretion of micro continents (Myers 1990, 1993). Krapez et al. (2000) and Brown et al. (2001)

9 interpreted the volcanic rocks in the craton to be associated with convergent margins, but other

10 people such as Campbell and Hill (1988) and Hill et al. (1992) argued that the Yilgarn craton formed

11 above a mantle plume. However, the geophysical data reported below shows no evidence to support

12 a plume model, such as low velocity holes that would record the passage of a plume. In the past few

13 decades, several specific subdivisions have been put forward for the Yilgarn craton (Gee 1979;

14 Myers 1993, 1995; Tyler and Hocking 2001; Cassidy et al. 2004, 2006). Based on the plate tectonic

15 environment, Cassidy et al. (2006) divided the Yilgarn craton into six terranes (Fig.3B): the Narryer

terrane, Youanmi terrane, Kalgoorlie terrane, Kurnalpi terrane and Burtville terrane. Among them the Kalgoorlie terrane, Kurnalpi terrane and Burtville terrane are known as the Eastern Goldfields superterrane (Fig.3B).

\section{Figure 3 around here}

Much of the continental crust in the Yilgarn craton was generated after 3.2 Ga (Griffin 2004a), and mainly between $\sim 2720$-2655 Ma which corresponds to the final assembly of different terranes (Huston et al. 2012). The oldest crustal components $(\sim 3.7 \mathrm{Ga})$ are identified in the middle of the craton (Griffin 2004a). Wilde et al. (2001) found samples in the region with the world's oldest

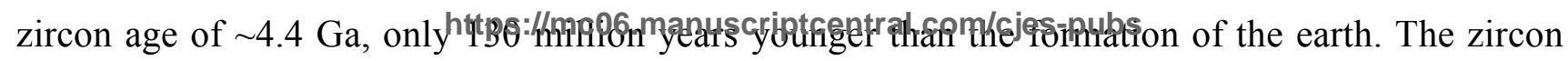


indicates the interaction of rocks with Earth's early hydrosphere, meaning that the ocean existed on earth before $\sim 4.4 \mathrm{Ga}$. Harrison et al. (2005) also supported that this zircon in the Yilgarn craton is older than $\sim 4.4 \mathrm{Ga}$ based on the measurement of initial ${ }^{176} \mathrm{Hf} /{ }^{177} \mathrm{Hf}$ values. Cassidy and Champion (2004) used $\mathrm{Rb}$ isotope and zircon data and combined the research on the upper crust by Swager (1997) and Krapez et al. (2000), and then determined that the western Yilgarn craton is older than the eastern parts.

Compared with the NCC, the Yilgarn craton has had a relatively simple tectonic evolution history (Table 2) since cratonization.

\section{Table 2 around here}

The Yilgarn craton finished cratonization at around $\sim 2655 \mathrm{Ma}$ (Czarnota et al. 2010; Huston et al. 2012). During $2215-1950$ Ma, the Pilbara craton collided with the Yilgarn craton during a muti-stage orogeny (Cawood and Tyler 2004). The Pilbara craton subducted under the Yilgarn craton, and formed the Capricon orogenic belt. Thereafter, these two cratons were combined as the West Australian craton (Cawood and Tyler 2004; Occhipinti et al. 2004). During the Yapungku-Capricorn orogeny at $\sim 1790-1780 \mathrm{Ma}$, the Western Australia craton subducted underneath the Northern Australia terrane (Bagas 2004; Giles et al. 2004) and formed a sinistral strike-slip fault along the SE margin of the Yilgarn craton (Huston et al. 2012). During 1345-1140 Ma, the amalgamation of the West Australian craton and the Mawson craton (include the South Australian Element and large parts of the east Antarctica continent; Boger 2011) formed the Albany-Fraser orogen (Myers et al. 1996; Smithies et al. 2010; Kirkland et al. 2011; Boger 2011). This orogeny mainly took place in two stages: 1345-1260 Ma (Stage I) and 1215-1140 Ma (Stage II; Clark et al. 2000; Bodorkos and https://mc06.manuscriptcentral.com/cjes-pubs 
1 Clark 2004). The Pinjarra orogen which lies to the west of the Yilgarn craton comprises elements of

2 the Australo-Antarctic and Indo-Antarctic domains (Cawood and Korsch 2008). The orogen was

3 formed during the oblique collision of these continental fragments at about 522Ma (Collins 2003;

4 Collins and Pisarevsky 2005). During the late Jurassic, India, Antarctica and Australia began to

5 separate from each other (Veevers 2006) and completed the process at about 120 Ma (Norvick and

$6 \quad$ Smith 2001; Veevers 2006).

\subsection{Lithospheric structure}

The SCLM of the Yilgarn craton is characterized by high seismic velocity, it is depleted and refractory, and has had little internal deformation since the Archean (e.g., Fishwick et al. 2005; Fishwick and Reading 2008; Jaques and Milligan 2004). Van Gerven et al. (2004) used data from

11 broad-band seismometers to compute the possible compositional changes of the upper mantle of 12 Australia. They calculated the relative density-to-shear velocity scaling $(\zeta)$ of each main block. At depths over $200 \mathrm{~km}$ under the Yilgarn craton, the $\zeta$ is negative, as a result, they speculated that the thickness of the SCLM is about $200 \mathrm{~km}$. Goleby et al. (2006) conducted a seismic survey line in the Eastern Goldfields superterrane, and according to their results the lithospheric thickness is about 220 $\mathrm{km}$. The tomographic results of Fishwick and Reading (2008) who used surface waves also support that the Yilgarn craton has a thick SCLM. Kennett and Blewett (2012) integrated different seismic data and then summarized the thickness of SCLM beneath the Yilgarn craton to be $200-250 \mathrm{~km}$. From north to south the lithospheric thickness has a tendency to become thinner, and from west to east to gradually thicken. Thick SCLM can also be inferred from the bouguer gravity anomaly map, 
1

Figure 4 around here

Although there is not much data from kimberlites in the Yilgarn craton, studies of the existing diamondiferous kimberlites show the lithospheric thickness beneath the Yilgarn craton is around 175 km or thicker (Jaques and Milligan 2004; Graham et al. 2004). Geothermal data also show that the Yilgarn craton preserves thick lithosphere (Jaupart and Mareschal 2005), the whole Western Australian craton including the Yilgarn and Pilbara are characterized by low heat flow ranging from 40 to $50 \mathrm{~mW} / \mathrm{m}^{2}$ (Jaupart and Mareschal 2005). There is not any evidence demonstrating anomalous geothermal gradients in the Yilgarn craton (Weber et al. 2005). In addition, limited decoupling between the crust and SCLM is suggested by the coincidence of the Proterozoic mantle magma with the Archean mantle magma (Blewett et al. 2010).

Xenoliths derived from the eruption of kimberlites in the northern and eastern parts of the Yilgarn craton yield additional information about the SCLM (Jaques and Milligan 2004). Xenocryst-poor kimberlites from the Eastern Goldfields Province (EGP; Fig.3B) yielded ages of $\sim 2025 \pm 10 \mathrm{Ma}$ (Graham et al. 2004). Additional age information of $\sim 1300 \mathrm{Ma}$ is recorded by xenoliths from the northern Yilgarn craton (Graham et al. 1999). Ultramafic rocks emplaced at about 1900-1700 Ma (Shee et al. 1999) are recorded by diamond bearing kimberlites from the northern Yilgarn craton. Besides that, the Northampton and Mullingarra complex (Fig.3B; located in the Pinjarra orogen) record deformation, magmatism and metamorphism that took place at around 1080 Ma (Bruguier et al. 1999; Cobb et al. 2001).

More recent data have shown heterogeneities within the Yilgarn craton and confirm that the lithosphere is characterized by fast seismic velocity, with a depleted and refractory mantle, and fast https://mc06.manuscriptcentral.com/cjes-pubs 
1 shear wave anomalies extending to more than $200 \mathrm{~km}$ (Simons et al. 1999, 2002; Reading and

2 Kennett 2003; Fichtner et al. 2009; Blewett et al. 2006, 2010; Fishwick et al. 2005, 2012; Fishwick

3 and Reading 2008; Ford et al. 2010; Kennett and Blewett 2012). Interestingly, Fishwick and

4 Reading (2008) point out that a distinct low velocity zone is observed at depths of 150-250 $\mathrm{km}$ in

5 the cross sections through the Archaean regions of the Yilgarn craton at $120^{\circ} \mathrm{E}$ (Fig.4B).

6 Checkerboard tests by Fishwick and Reading (2008) have verified the reliability of Fig.4. Both

7 perturbations and absolute velocities figures (Fig.4B) indicate that anomalies exist at depths of

$8 \quad 150-250 \mathrm{~km}$ beneath the southern margin of the Yilgarn craton. Ford et al. (2010) carried out Sp

9 receiver functions to detect the lithosphere-asthenosphere boundary beneath Australia. The

10 calculated results of stations in the southern Yilgarn craton only show an anomaly at a depth of

11 about $90 \mathrm{~km}$, which they interpreted as a mid-lithospheric discontinuity (MLD), but they did not

12 find any anomaly at greater depths that can represent the lithosphere-asthenosphere boundary

13 (LAB). Therefore, this anomaly interface could also be interpreted as the lithosphere-asthenosphere

14 boundary, which indicates a thinned lithosphere beneath the southern Yilgarn craton.

Seismic data above shows that the Yilgarn craton maintained stability and preserves a thick

lithosphere root of about $200 \mathrm{~km}$, no abnormal velocity area was imaged beneath the interior of the speed with perturbation of around $-2 \%$ to $-4 \%$ from $100 \mathrm{~km}$ to $150 \mathrm{~km}$ (Fig.4A), which is quite different from the interior area, and no more anomaly at greater depths that represent the lithosphere-asthenosphere boundary (LAB) can be found in this area from the seismic data.

21 Therefore the lithosphere of the southern margin is much thinner than other parts of the Yilgarn 
local parts near the Albany-Fraser orogen. Geothermal and geochemistry data reflect that the Yilgarn craton is different from the eastern NCC and it is still a typical stable Archean craton.

\section{Superior Craton}

\subsection{Geologic setting}

The Superior craton (Fig.5) which is located in Canada is the largest craton in the world and the nuclei of the North American continent (e.g., Thurston 2002), covering an area of about 1.6 million $\mathrm{km}^{2}$. The Archean Superior craton mainly contains Archean linear belts of volcanic-plutonic rocks, metasedimentary belts, and high-grade gneiss belts (Fig. 5). Most of these rocks formed between $\sim 2.8$ to $\sim 2.7 \mathrm{Ga}$ (Hoffman 1989). Since its formation around $\sim 2.7 \mathrm{Ga}$ through the accretion of arcs, accretionary prisms, and ribbon microcontinents (Burke et al. 1976; Card and Poulsen 1998; Percival et al. 2006; Evans and Halls 2010), the Superior craton only experienced minor deformation. The Kapuskasing Structural Zone (KSZ; Fig.5B) divides the Superior craton into western and eastern parts (Percival and McGrath 1986; Evans and Halls 2010). The western part mainly comprises granite-greenstone and metasedimentary belts or subprovinces (Ferguson et al. 2004) with east-west trends, which formed during the progressive accretion of arcs and micro-continents (e.g., Thurston et al. 1991; Kusky and Polat 1999; Percival et al. 2006). The Superior craton is also surrounded by orogenic belts (Fig.5A), including the Trans-Hudson orogen to the northwest ( 1.8 Ga; Hoffman 1988), the Penokean orogen ( 1.9-1.6 Ga; Ludden and Hynes 2000; Schultz and Cannon 2007) to the south as well as the Grenville Province to the southeast ( 1.3-1.0 Ga; Hoffman 1988; Thurston 2002; Ludden and Hynes 2000; Tohver et al. 2004, 2005). 


\section{Figure 5 around here}

The Superior craton formed during $\sim 3.0-2.6$ Ga through a series of magmatic arc complexes added by accretion events from the south (Card and Poulsen 1998; Percival et al. 2006). Since the late Archean, the craton has always kept a relatively stable state (Table 3; Thurston et al. 1991; Percival et al 2006; Frederiksen et al. 2007). Granite rocks intruded the craton during a short time after its cratonzation. In the early Paleoproterozoic, numerous dyke swarms intruded the Superior craton and its southern margin developed sedimentary basins (Buchan and Ernst 2004; Bleeker and Ernst 2006). After $\sim 2.0 \mathrm{Ga}$, the marginal regions of the Superior craton began to change to convergent tectonic regimes (Hoffman 1988; Ernst et al. 1995, 2014; Schulz and Cannon 2007).

The Archean Superior craton collided with the west Churchill Province between $1.9-1.8 \mathrm{Ga}$, forming the Trans-Hudson orogen (Fig.5A; Eaton and Darbyshire 2010 and references therein; Schneider et al. 2007). The collision occurred after the closure of the Pacific-scale Manikewan Ocean (Eaton and Darbyshire 2010). Between $\sim 1890 \mathrm{Ma}$ and $\sim 1830 \mathrm{Ma}$, an island arc collided with the Superior craton on the southern margin and ended the southward subduction, forming the Penokean orogen (Schultz and Cannon 2007). A notable intracratonic area in the Superior craton is the Kapuskasing Structural Zone which suffered significant deformation and brought deep-crustal rocks to the surface. The deformation is considered to be a response to collisional and orogenic events at about $\sim 1.9 \mathrm{Ga}$ (Percival and Peterman 1994). Later the region was affected by the Keweenawan Mid-continent rift between $1.11-1.09$ Ga (Thurston et al. 1991). The Mid-continent rift is a major structure that formed in an event that affected the southern Superior craton. It is a major continental rift in the world, extending about $2300 \mathrm{~km}$ in the central North America. The

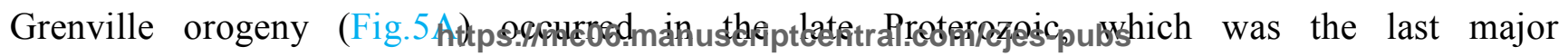


accretionary/collisional event forming the Canadian Shield (Hoffman 1988; Thurston et al. 1992).

The orogeny includes two stages, the older one is the collision between Laurentia and Amazonia during $\sim 1.2-1.12 \mathrm{Ga}$, the younger one is interpreted to represent intracratonic strike-slip at $\sim 1.1 \mathrm{Ga}$ (Corrigan and van Breemen 1997; Tohver et al. 2005).

\section{Table 3 around here}

\subsection{Lithospheric structure}

Studies of surface waves from the western Superior craton (Darbyshire et al. 2007; Darbyshire and Lebedev 2009) suggest that the thickness of lithospheric root extends more than $200 \mathrm{~km} \mathrm{(Fig.6),}$ including the $40 \mathrm{~km}$ thick crust (Kendall et al. 2002). Sol et al. (2002) even estimated the thickness of the cratonic root of the western Superior craton to be around $300 \mathrm{~km}$ based on both P- and S-wave anomalies. Beneath the central regions of the Superior craton, the inferred thickness of lithosphere changes from $140 \mathrm{~km}$ to $200 \mathrm{~km}$, and some areas in the center are estimated to be between $200 \mathrm{~km}$ to $240 \mathrm{~km}$ thick (Darbyshire et al. 2007). The depth of the lithosphere beneath Hudson Bay is generally greater than $180 \mathrm{~km}$ (Darbyshire et al. 2011). The continental-scale shear wave velocity models of

North America show that most areas of the Superior craton are dominated by significant high-velocity anomalies to a depth of 200 km (e.g., Godey et al. 2004; van der Lee and Frederiksen 2005).

\section{Figure 6 around here}

The tomographic velocity model derived by Frederiksen et al. (2007) shows the variation of lithospheric thickness across the Superior craton. The western part represents high velocity while the https://mc06.manuscriptcentral.com/cjes-pubs 
eastern part is characterized by low velocity (Fig.6). The checkerboard resolution tests done by

Frederiksen et al. (2007) used three-dimensional checkerboard patterns of alternating positive and negative spike anomalies, and excellent recovery of the input model indicates that the given seismic image (Fig.6) in this paper is reliable within at least $200 \mathrm{~km}$ in the vertical direction. Surface wave studies (Darbyshire et al. 2007) also show that the Superior craton exhibits large variations in lithospheric thickness ranging from $100 \mathrm{~km}$ to almost $220 \mathrm{~km}$. The regions showing this difference are separated by a NNW-SSE oriented boundary (Fig.6) which also divides the regions with weak and strong shear wave splits (Darbyshire et al. 2007). In addition, they also discovered a 200-km-thick low-velocity anomaly corresponding to the failed-branch (Fig.6) of the $\sim 1.1 \mathrm{Ga}$ Keweenawan Mid-continent rift, and a linear low-velocity anomaly which may be caused by the Great Meteor hot spot track (Heaman et al. 2004).

The thick lithosphere extended to the diamond stability field beneath the Wawa area (Fig.5B; the southern Superior craton) prior to $\sim 2.7 \mathrm{Ga}$, as inferred from studies of diamonds in Neoarchean lamprophyres and related volcaniclastic breccias (Stachel et al. 2006; De Stefano et al. 2006). Furthermore, diamonds contained in the $\sim 2.697-2.700$ Ga Wawa metaconglomerate were derived from the depleted mantle (Smith et al. 2012). Geothermal data of the Neoarchean Superior craton

17 show that the maximum heat flow is about $41 \mathrm{~mW} / \mathrm{m}^{2}$ (Drury and Taylor 1987), and the inferred lithospheric thickness from the geothermal data for the southern Superior craton was at least $190 \mathrm{~km}$ at that time. Mantle xenoliths of coarse and deformed garnet peridotites (Meyer et al. 1994; Vicker 1997) from the Jurassic Kirkland Lake (also located in the southern margin of Superior craton;

21 Fig.5B) kimberlites (Heaman et al. 2004) show a different situation. These garnet peridotites were

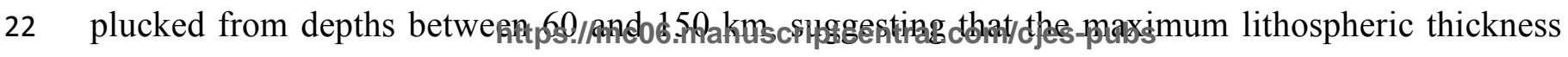


was $150 \mathrm{~km}$ in the Jurassic. Griffin et al. (2004b) carried out a study on the composition of the mantle below Kirkland Lake based on the geochemistry of garnet macrocrysts. The results indicate that the upper mantle above $135 \mathrm{~km}$ is a typical Archean cratonic root. Below that depth, the mantle is marked as metasomatized and fertile lherzolites, indicating a modified cratonic root (Griffin et al. 2004b). In addition, current geophysical data from the southern Superior craton have shown that the lithospheric thickness is no more than $150 \mathrm{~km}$ (Fig.6; Faure et al. 2011; Frederiksen et al. 2007). Fig. 6 clearly shows that the Wawa area is dominated by low velocity with perturbation of around $-2 \%$ below $100 \mathrm{~km}$. That means the SCLM thinning also occurred along the southern margin of the Superior craton. The SCLM thinning in areas adjacent to the Mid-continent rift happened before 1.1 Ga (Miller et al. 2012), because the maximum thickness of the SCLM of the area inferred from the peridotitic garnet xenocryst's formation was already less than $150 \mathrm{~km}$ at $\sim 1.1 \mathrm{Ga}$ (Kaminsky et al. 2002).

Queen et al. (1996) reported ${ }^{40} \mathrm{Ar} /{ }^{39} \mathrm{Ar}$ phlogopite ages for a number of $\sim 1140 \mathrm{Ma}$ lamprophyres from kimberlites in the Wawa area (Fig.5B). Also the Pele perovskite (in the Wawa area) yields an age of $\sim 1172.3 \pm 4.6 \mathrm{Ma}$ (Heaman et al. 2004). The kimberlites from Kyle Lake have ages of about $\sim 1076.2 \pm 3.8 \mathrm{Ma}$ (Sage 2000; Kaminsky et al. 2002). A Jurassic kimberlite pipe (Meyer et al. 1994; Vicker 1997) near Kirkland Lake (Fig.5B) contains xenoliths with two main stages of zircon growth. The first main stage of growth is around $\sim 2584 \pm 7 \mathrm{Ma}, \sim 2629 \pm 8 \mathrm{Ma}$, $\sim 2633 \pm 3 \mathrm{Ma}$, the younger one is between $\sim 2.52 \mathrm{Ga}$ and $\sim 2.40 \mathrm{Ga}$ (Moser and Heaman 1997). In addition, the xenoliths there also show ages between $\sim 157-152$ Ma. The Attawapiskat kimberlites record age information at around $\sim 180 \mathrm{Ma}$ and the Timiskaming kimberlites have ages between

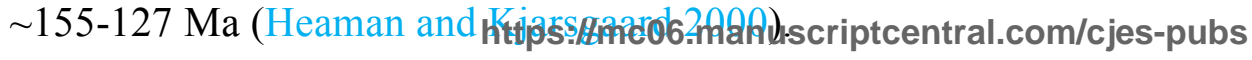


Scully et al. (2004) did a geochemical analysis on xenocrysts contained in kimberlites in the

Superior craton. The results show that a number of xenocrysts are similar with others found in other Archean cratons. However, significant variations in the garnet composition were also observed. Changes in mantle depletion with depth were inferred from the Rare-Earth Element features of different Mesozoic kimberlite pipes. Lithosphere with depths less than $120 \mathrm{~km}$ exhibits compositions which are closer to the primitive upper mantle (Scully et al. 2004). The Proterozoic pipes show greater depths of origin. Therefore, they proposed that the upper mantle of the Superior craton is highly heterogeneous.

Present heat flow models of the Superior craton indicate that the average geothermal gradient is about $42 \mathrm{~mW} / \mathrm{m}^{2}$ (Drury and Taylor 1987), which is almost the same as the worldwide average for Archean crust (41 mW/ $\mathrm{m}^{2}$; Nyblade and Pollack 1993). Research on the heat flow from 9 deep boreholes in the western Superior show that flow value is between 31 and $56 \mathrm{~mW} / \mathrm{m}^{2}$, and the mean heat flow is $42 \pm 8 \mathrm{~mW} / \mathrm{m}^{2}$ (Rolandonc et al. 2003). Perry et al. (2006b) also pointed out that the mean surface heat flow for the Superior craton is $40.9 \pm 0.9 \mathrm{~mW} / \mathrm{m}^{2}$ based on 70 land determinations. The Abitibi subprovince (Fig.5B) is distinguished from the rest of the craton, where large volumes of greenstones are responsible for the relatively high heat flow value in this area (Mareschal and Jaupart 2004). Geophysical and geochemical evidence presented above indicate that the Superior craton is underlain by lithospheric mantle that exhibits strong regional variations in anisotropy, velocity structure and composition (Darbyshire et al. 2007; Scully et al. 2004). The lithosphere has been thinned beneath the southern margin and xenolith data record a possible related event at about $\sim 1.1 \mathrm{Ga}$. On a larger scale, the Superior craton still has a thick SCLM (Carlson et al. 
1

2

\section{Discussion}

\subsection{Subduction polarity}

When oceanic lithosphere subducts beneath cratons, water is carried into the mantle via hydrous mineral phases in the slab and overlying sediments, and the most important dehydration reactions occur at the facies transition from blueschist to eclogite, which releases abundant water to the overlying mantle (Peacock 1993). This hydrates and thereby weakens the upper mantle and therefore lowers the melting temperature (solidus), and decreases the mantle viscosity (Komiya and Maruyama 2006; Sandu et al. 2011; Kusky et al. 2014b). Water would preferentially be removed with the melt in the partial melting process of mantle peridotite and pyroxenite, leading to the formation of refractory lithospheric mantle (Karato 1986; Hirth and Kohlstedt 1996). The higher degree of mantle melting would eliminate more water and result in greater stability of the lithospheric mantle. Therefore, water plays a key role in the formation, modification and destruction process of the craton (Niu 2005; Maruyama and Okamoto 2007; Kusky et al. 2007a, 2014b). Thus, the long-lived subduction beneath the craton is important to its destruction. On the contrary, when subduction is dipping away from a craton, the hydration of the mantle is very limited which greatly contributes to the preservation of the SCLM. collisional events (Table 1; Maruyama et al. 2007; Windley et al. 2010; Xiao et al. 2003, 2009a, b; Kusky et al. 2007a, 2014b), and most polarities of the subduction were toward and underneath the

NCC. For example, the Yangtze craton subducted underneath the NCC in the Permo-Triassic, the

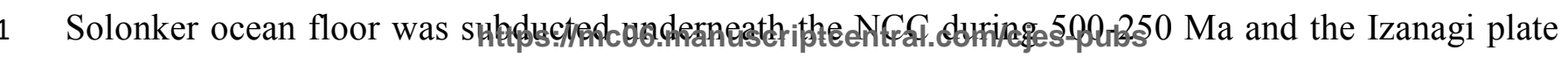


1 also dipped underneath the NCC during 200-100 Ma. These subduction events (especially the

2 long-term subduction of the Izanagi plate during the Cenozoic) are suggested to have led to

3 remarkable hydroweakening of the lithosphere, which promoted the generation of melts and the

4 interaction with the overlying SCLM (Maruyama and Okamoto 2007; Windley et al. 2010; Kusky et

5 al. 2007a, 2014b). The oceanic lithosphere that subducted underneath the NCC is estimated to be

6 more than any other craton on the Earth (Kusky et al. 2007b; Windley et al. 2010), and the loss of

7 the SCLM of the eastern NCC is related to the ingress of large amount of water released by the

8 subducted oceanic lithosphere. The dehydration of oceanic lithosphere triggered partial melting in

9 the overlying mantle wedge and played a key role in the generation of hydrous magmas which

10 reduced the viscosity of the lithosphere and made it behave similar to the asthenosphere, therefore

11 setting the stage for the loss of the SCLM (Kusky et al. 2014b). Consequently this gave rise to the

unsteadiness of mantle convection beneath the NCC, which softened the lithosphere and made it

easy for delamination or SCLM erosion to take place in the interior of the craton (e.g., Sleep 2005). also dipped away from the Yilgarn craton during the oblique collision (Table 2) of the Australo-Antarctic and Indo-Antarctic elements. Regarding to the Superior craton (Table 3), when an island arc collided with the Superior craton on the southern margin and forming the Penokean orogen, the subduction was away from the Superior craton. The subduction still dipped away from 

9 long-term history of dipping away from the craton. cratonic characteristics.

\subsection{Marginal Lithospheric thinning} has occurred.

\section{Yilgarn craton}

orogeny). So in these cases, the influence to the SCLM is limited. With almost no subduction and mantle hydration beneath the craton, which provides advantages for preserving the SCLM, this is the main reason that the Yilgarn and Superior cratons still maintained stability and currently still have

As the subduction polarity controls the water released to the SCLM and water plays a key role in the formation and destruction of cratons, subduction polarity has a great effect on craton destruction. Based on the tectonic events that the NCC, Yilgarn and Superior cratons experienced, it is reasonable to conclude that the SCLM is more likely to be preserved when subduction has a

During the comparison of geological, geophysical and geochemical data of the three cratons, we found that the Yilgarn craton and Superior craton remained stable as a whole and also show properties of typical cratons, but lithospheric thinning still occurred in local regions. Geophysical data show that these regions are limited to the craton margins where plate subduction or collision

Seismic data combined with geothermal data show that most areas of the Yilgarn craton have lithosphere more than $200 \mathrm{~km}$ thick, while the situation beneath the southern margin is a little different. Fishwick and Reading (2008) have shown that the southern margin of the Yilgarn craton

(Fig.4A; south of $32^{\circ} \mathrm{S}$ ) is an abnormal area with low seismic velocities between 150 and $250 \mathrm{~km}$ (Fig.4B), but they presented no speculations about the reason. Considering the area is inside the https://mc06.manuscriptcentral.com/cjes-pubs 
craton and far away from the continent-ocean transition region, and the depth of the lithosphere is much shallower than other marginal areas of the craton inferred from the seismic image (Fig.4B), this area most affected by subduction events. Therefore we suggest that it is cratonic lithosphere which has been thinned.

5

The area is close to the Albany-Fraser orogen (Fig.3B) which formed in the collision between the west Australian craton and the Antarctic continent (Myers et al. 1996) during 1345-1140 Ma. From the perspective of space, the area with lithospheric thinning corresponds to the Albany-Fraser orogen. In addition, in the aspect of time, scarcely any tectonic events could have had effects on the SCLM around the region except the Albany-Fraser orogeny during the evolution of the Yilgarn craton. Based on U-Pb, Lu-Hf and Sm-Nd data, Kirkland et al. (2011) also suggested that the southern margin of the Yilgarn craton has been re-worked during the formation of the Albany-Fraser orogen. Therefore, the convergence between plates is most likely to be the dynamic factor of the thinning of the SCLM at this region. So far, there are scantily few xenolith data from the Yilgarn craton, while xenocryst-poor kimberlites in the Jewill field (Fig.3B) and lamprophyre contained in the Buljah field record age information of $\sim 1300$ Ma (Graham et al. 1999). Besides that, the Northampton and Mullingarra complex (basement of the Pinjarra orogen; Fig.3B) record that the deformation, magmatism and metamorphism took place at around $\sim 1080$ Ma (Bruguier et al. 1999; Cobb et al. 2001). The age information contained in the xenoliths and deformation at about $1080 \mathrm{Ma}$ may have connections with the subduction and collisional events during the Albany-Fraser orogeny for the time is coincident but there is not any clear geological evidence. If this hypothesis is proven true, then this would provide solid evidence that the abnormal area with low velocity was caused by

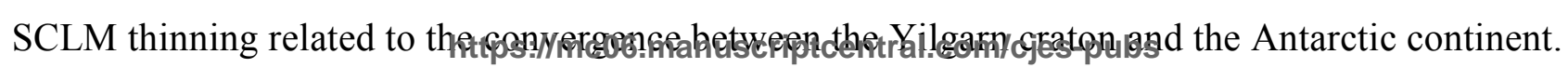




\section{Superior craton}

Evidence from geochemistry and geothermal data show that the lithospheric thickness of the southern margin of the Superior craton thinned from at least $190 \mathrm{~km}$ in the Neoarchean to the maximum thickness of $150 \mathrm{~km}$ in the Jurassic and geophysical data also shows that the lithosphere beneath the southern margin of the Superior craton is quite different from the other parts. Miller et al. (2012) proposed that the diamondiferous root below the southern Superior craton has disappeared, and the lithospheric thinning beneath the southern Superior may be caused by tectonic erosion, craton amalgamation, and ingress of asthenospheric fluids. However, they did not have a clear explanation for the specific dynamic reason for the lithospheric thinning. The thick lithosphere extending to the diamond stability field existed beneath this area (the Wawa area; Fig.5B) prior to $\sim 2.7 \mathrm{Ga}$, which was inferred from studies of diamonds in the Neoarchean lamprophyres and related volcaniclastic breccias (Stachel et al. 2006; De Stefano et al. 2006). However, detailed geophysical data presented in section 4.2 shows that the southern Superior craton does not have high seismic velocities indicative of lithosphere thicker than $150 \mathrm{~km}$ (Frederiksen et al. 2007; Faure et al. 2011).

Geochemical studies of garnet macrocrysts from the mantle below Kirkland Lake also suggest that the cratonic root has been modified since the lithosphere below $135 \mathrm{~km}$ is characterized by metasomatized and fertile lherzolites (Griffin et al. 2004b).

After cratonization of the Superior craton, its southern margin experienced the Penokean orogeny and Keweenawan Mid-continent rifting events. Both events may have caused lithospheric thinning, but combined with the age data contained by the xenoliths for the timing of tectonic events, we can have a better estimation about which dynamic factor caused lithospheric thinning. 
1 lamprophyres (Queen et al. 1996), 1172.3 \pm 4.6 Ma perovskite (Heaman et al. 2004), showing that

2 the SCLM has been affected during $\sim 1150 \pm 20 \mathrm{Ma}$. The Keweenawan Mid-continent rift formed

3 before $\sim 1.1$ Ga (Thurston et al. 1991) and the Penokean orogeny took place between $\sim 1.9-1.6$ Ga

4 (Ludden and Hynes 2000). According to the evidence provided by xenoliths, the SCLM thinning

5 beneath the southern margin was more likely caused by the Keweenawan Mid-continent rifting event.

6 Based on the major and trace element chemistry of garnets from kimberlites and alkaline intrusions,

7 Scully et al. (2004) proposed that the mantle metasomatism in the southern Superior craton is

8 contemporaneous with the $\sim 1.1 \mathrm{Ga}$ Mid-continent rift system. This major continental rift certainly

9 had great significance in the modification of the mantle lithosphere. The peridotitic xenoliths from

10 the Jurassic kimberlite near Attawapisk (Fig.5B) also provide evidence that the lithosphere of the

11 Wawa-Abitibi terrane in the southern Superior craton was affected by the Mid-continent rift. The

$12 T_{R D}$ ages (Re depletion ages) of these xenoliths is between $\sim 1.6$ and $\sim 1.4 \pm 0.2$ Ga (Smit et al. 2014),

13 which are consistent with $\sim 1.5$ and $\sim 1.1$ Ga whole-rock $T_{R D}$ ages for xenoliths from Kirkland Lake

14 in the southern Superior craton (Pearson et al. 1997). These whole-rock $T_{R D}$ ages are interpreted as

15 mixing ages derived during the ingress of the Mid-continent rift related melt into the Archaean

16 Superior lithospheric mantle (Smit et al. 2014).

Active rifting is thought to be caused by the interaction between plates (Sengör and Burke thermo-chemical erosion (Zheng and Wu 2009). Gordon et al. (1986) explained the origin of the Mid-continent rift as a result of the Grenville orogenic event based on evidence from isotope ages. Furthermore the Mid-continent rift is located in the Penokean orogen which underwent muti-stage 
1 thinning along the southern margin of the Superior craton is essentially affected by plate convergence.

\section{Comparison with the NCC}

Studies show that the convergent events along the southern NCC, western subduction of the Izanagi plate and southern subduction and collisional events occurred at the northern margin of the NCC are responsible for the lithospheric thinning beneath the southern and northern margin and also had great effect on craton destruction (Deng et al. 2007).

\section{Northern margin of the NCC}

The reactivation and subsequent orogenesis along the northern margin of the NCC were initiated in the late Paleozoic (Y. Wang et al. 2013; Z. Zhang et al. 2014). Geochemical and isotopic compositions of the Triassic Shuiquangou (Fig.1A) volcanic rocks and basic-ultrabasic complex and granitic intrusive rocks from the northern margin of the NCC shows that the asthenosphere was involved in the formation of these rocks (Zhang et al. 2010). However, no mid-ocean ridge or hotspot existed on the northern margin of the NCC during the Mesozoic. These depleted asthenospheric mantle compositions may come from decompressional melting of upwelling asthenospheric mantle caused by the post-collisional orogenic extension and collapse. Therefore, the convergent events would be expected to modify the lithosphere along the northern margin of the NCC (Zheng et al. 2012). As the upwelling of asthenospheric mantle and the evidence for an asthenospheric source composition in magmatic rocks are regarded as the beginning of destruction, lithospheric thinning of the northern margin of the NCC may have already started in the late Triassic. The upwelling of asthenosphere modified the SCLM by providing heat and reactions between melts

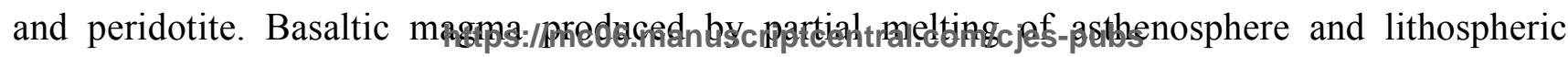


mantle even ascends to the crust-mantle boundary. So from the Paleozoic to early Mesozoic, the closure of the Paleo-Asian Ocean and subsequent collision modified the lithosphere of the northern

3 NCC.

Xenolith data described in section 2.2 including age information of $\sim 645 \pm 225 \mathrm{Ma}$ (Yu et al. 2007), 470 Ma (Zhang et al. 2012) and 462 Ma (Zhang et al. 2011) from the northern margin of the NCC, suggesting that the northern NCC suffered reworking during the Paleozoic. From the evolutionary history of the NCC, we conclude that the age information contained in the xenoliths corresponds to the time of subduction of the Paleo-Asian Ocean and collisional events after that, which means that the convergence between plates affected the SCLM (Zheng et al. 2012). All of this temporal evidence from xenoliths demonstrates that the lithospheric thinning of the northern

11 NCC was related to the convergence between plates.

12

13

14

\section{Southern margin of the NCC}

Paleozoic ( 377-260 Ma) and early Mesozoic ( 228-219 Ma) zircons are also found in eclogites and peridotites derived from Qinling-Dabie-Sulu Orogenic Belt (Fig.1B), showing the modification of the lower crust and the uppermost mantle (Zheng et al. 2012). Liu et al. (2013) reported the Mesozoic Jiagou (Fig.1B) dioritic porphyry has an average age of $\sim 393 \pm 7$ Ma. In addition, $80 \%$ of zircons in the eclogite xenoliths from the Xinyang area give Paleozoic $(\sim 377-263$ Ma) U-Pb ages (Zheng et al. 2012), indicating that the southern margin of the NCC suffered intense modification during that time. This age information contained in xenoliths point out that the convergence between the Yangtze craton and the NCC was responsible for the reworking of the southern NCC. Zheng et al. (2005) studied peridotite xenoliths in the early Mesozoic volcanic rocks

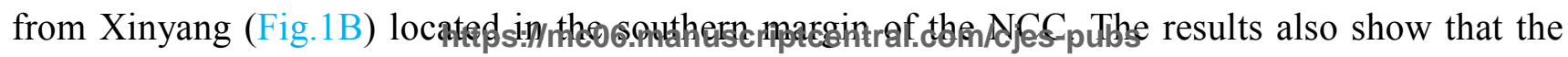


1 SCLM beneath the southern NCC has been modified by the convergence between the Yangtze and

2 North China cratons. Zheng et al. (2012) compared the mantle inclusions in volcanic rocks derived

3 from different locations (such as the centre and margin of plate, Tan-lu fault) and different time (e.g.,

4 the Paleozoic, Mesozoic and Cenozoic), and the peridotite from the southern NCC and Dabie-Sulu

5 ultrahigh pressure metamorphic zone, and pointed out the inhomogeneity among the structure and

6 composition of the SCLM. They suggested that the integrity of the NCC was destroyed by the

7 subduction and collision of Yangtze craton during Triassic times.

8

9

The descriptions above suggest that subduction and collisional events at the northern and southern margin of the NCC in the Paleozoic were responsible for the SCLM thinning beneath the northern and southern margin of the NCC and also played a key role in the early destruction of the eastern NCC. L. Wang et al. (2014) also showed that melts derived from deeply subducted eclogite in the Sulu orogen infiltrated the base of the NCC SCLM at circa 228-219 Ma, further enhancing destruction of the base of the southern NCC.

All three cratons discussed here have experienced different degrees of lithospheric thinning beneath their marginal regions. The convergence between plates can affect the SCLM, which is the dynamic cause of marginal lithospheric thinning, at the same time it can only cause the SCLM thinning of the marginal areas but have almost no effect on the internal regions of a craton. Here we emphasize that craton destruction includes lithospheric thinning and the essential change of the nature of the lithosphere and the thermal state, which is different from lithospheric thinning (Zhu et al. 2012). Thus, craton destruction is not always accompanied by lithospheric thinning, except for cratons which suffered subduction and collision from multiple sides. Therefore, subduction and collision from multiple side 


\subsection{Protection by weak zones}

An interestingly similar feature among the western NCC, Yilgarn and Superior cratons which all preserve thick SCLM, is that they are all surrounded by younger orogens (Fig.1A, Fig.3A, Fig.5A). The multiple periods of orogenesis of the surrounding belts indicates that stress induced by collision, without significant deformation of the cratonic interiors, is concentrated in these weak zones around the craton. Thus the orogens may shelter the craton from deformation, which contributes to the long-term stability of the craton (e.g., Lenardic 2000, 2003).

Windley (1995) observed that Archean cratons are typically surrounded by younger mobile belts, but the mechanical relationship between these two types of tectonic units has not been totally understood. A series of numerical studies suggest that as soon as a craton is surrounded by weak zones, the stress associated with mantle convection is buffered and the craton is prevented from being further deformed (Lenardic et al. 2000, 2003; Yoshida 2012). Results of these numerical studies suggest that the weak (low-viscosity, e.g., mobile belts) continental margin contributes most to the longevity of the SCLM (Yoshida 2010, 2012). The long-lived and inherited weakness of mobile belts can increase the longevity of cratonic roots by buffering the craton from mantle derived stresses. Because the stresses induced by collision between plates are transmitted to the SCLM by the weaker lithosphere of the mobile belt, the stress level that the SCLM experiences when suffering collisional events is below its yield stress (Lenardic et al. 2000). This prevents lithospheric failure and allows the high viscosity of cratonic lithosphere to resist mantle recycling (Lenardic et al. 2000).

The following section shows how this general phenomenon is appropriate for all three studied cratons. 
The viscosity of the lithosphere beneath grabens around the Ordos Block is lower than that of

17
the Ordos Block by 1-2 orders of magnitude (Zang et al. 2007). The two grabens around the Ordos Block correspond to the tectonic belt that existed in the NCC since the Archean. The Yinchuan-Hetao rift is located in the Paleoproterozoic North Hebei orogen (Fig.1B; Kusky et al. 2007c) and the Shanxi-Shaanxi rift roughly coincides with the Central Orogenic Belt (Fig.1B) that formed when the western block collided with the eastern block at about 2.4-2.1 Ga (Kusky 2011; Kusky and Mooney 2015). Compared to the core part of the Archean craton, these tectonic belts may have remained relatively weak since their formation, and they have been affected by multiphase tectonic events during the long-term evolutionary process. Therefore, these areas have been modified or even thinned which is indicated by the geophysical data (see details in section 2.2). As differences of properties (even the thickness) exist between the craton and mobile belts, the tectonically weak belts around the Ordos Block are more likely to be affected by tectonic events. Studies show that the latest Cenozoic lithospheric modification may be attributed to the far-field effects of both Pacific plate subduction and the India-Eurasia collision (Deng et al. 2004; Xu 2007; Jiang et al. 2013). It is the modification and thinning of lithosphere beneath these weak zones that reduced the total stress that the craton suffered, which protected the western NCC from destruction. Comparison of rheology of the SCLM beneath the eastern and western parts of China by Wang et al. (2001) indicates that the overall strength of lithosphere beneath extensional basins of the eastern part is relatively weak, with numerous ductile layers in the crust, while the western contractional basins have relatively high lithospheric strength. Numerical studies (Lu et al. 2011) indicate that higher strength of the lithosphere would increase the probability of the formation of

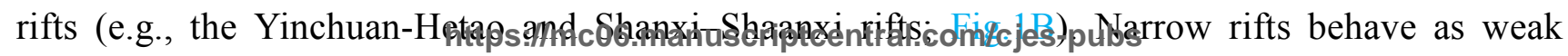


1 zones that reduce the total stress within craton and help to stabilize the craton (Lu et al. 2011).

2 Lithosphere with relatively low strength is more likely to deform uniformly without localized

3 deformation. Therefore, wide rifts are usually observed in destructed cratonic areas, e.g. the eastern

4 NCC. In addition, Lu et al. (2011) used numerical modeling to show that a craton in a cold thermal

5 state is more inclined to experience localized deformation. On the contrary, a craton with a hot

6 thermal state tends to experience widespread or uniform deformation. On the other hand, relatively

7 dry lithosphere would develop localized deformation easier than wet lithosphere. Thus, cratons can

8 develop localized deformation (e.g., narrow rifts) to keep their stability and protect the remaining

9 parts of the craton from subsequent deformation, which provides a reasonable explanation for the

10 destruction of the eastern NCC and the preservation of the western NCC. The western NCC has

11 higher lithospheric strength, and a relatively dry lithosphere with a cold thermal state. It experienced

12 localized deformation (e.g., the Yinchuan-Hetao and Shanxi-Shaanxi rifts), and these weak zones

13 kept the remaining parts of the western NCC stable. In contrast, the eastern NCC is more likely to

14 have uniform and widespread deformation due to its low lithospheric strength, hot thermal state and

15 water-rich lithosphere.

\section{Yilgarn craton}

The Yilgarn craton represents a similar situation to the western NCC, as it is surrounded by 
1 Capricorn orogeny, and a unnamed event at the end of the Palaeoproterozoic $(\sim 1670-1620 \mathrm{Ma})$,

2 reflecting that the weak mobile belts are the focus of stress. Hence, these orogens sheltered the

3 Yilgarn craton from deformation. The Albany-Fraser orogeny also occurred in two stages

4 (Pisarevsky et al. 2003; Clark et al. 2000; Bodorkos and Clark 2004) during 1345-1140 Ma, which

5 suffered most of the stress related to the convergent events. The Pinjarra orogen records (Fig.3A) a

6 complex history involving multiple stages of reactivation from the Mesoproterozic to early

7 Cambrian (e.g., Fitzsimons 2003; Boger 2011). However, the Yilgarn craton has remained stable

8 since its cratonzation in the Archean. The different tectonic evolution between the Yilgarn craton and

9 Pinjarra orogen show that the Pinjarra orogen accommodated the orogenic stresses through

10 deformation owing to its relatively low lithospheric strength. Consequently, the deformation induced

11 by intra-plate stresses of East Gondwana during the Permian and early Cretaceous would

12 preferentially be concentrated in the Pinjarra rather than the adjacent craton (Hall et al. 2013).

13 Therefore, these weak zones are significant to the stability of the Yilgarn craton.

\section{Superior craton}

The Superior craton has remained stable since the late Archean except for the formation of the

and Halls 2010) took place in this region, while the surrounding areas remained relatively stable. 
1 Cannon 2007; Tohver et al. 2004, 2005). As a consequence, this contributes to the long-term stability

2 of the Superior craton.

Lenardic et al. (2003) concluded that the degree of yield stress variation between mobile belts and cratons is found to be an effective and robust means for providing the longevity of the cratonic

5 lithosphere. In fact, similar to the western North China craton, local modification or thinning of the

6 SCLM and strong differences of crust-mantle structure between the nuclei of cratons and the 7 surrounding mobile belts have also been observed in South Africa (Fouch et al. 2004), Europe 8 (Gregersen et al. 2010), Siberia (Lesne et al. 2000), East Africa (Keranen and Klemperer 2008), and 9 North America (Barruol et al. 1997; Yuan and Romanowicz 2010). Numerical simulation research as 10 described above have already confirmed that the tectonically weak regions can protect cratons from 11 deformation for long periods of geologic time (Lenardic et al. 2000, 2003; Lu et al. 2011; Yoshida 12 2010, 2012), which is an important factor for the long-term stability of cratons. In this paper we expounded this general phenomenon and pattern in the evolution of cratons using specific examples.

\section{Conclusion} would add water and hydroweaken the underlying mantle, which softened the lithosphere and made it easy for delamination or SCLM erosion to take place in the interior of the craton. Finally, the combination of interior lithospheric delamination or SCLM erosion and marginal lithospheric thinning caused by convergence between plates from multiple sides may have led to decratonization

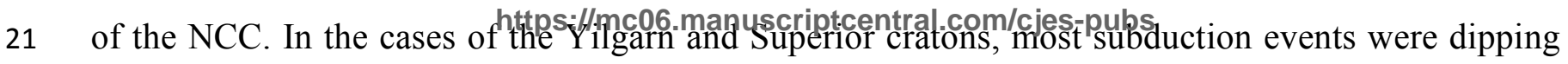


away from cratonic interiors, and the marginal lithospheric thinning area is limited. Furthermore, the

6
weak zones around these two cratons provide advantages for their long-term stability which is the same as the western NCC. Collectively these factors lead to the phenomenon that some cratons lose their roots (e.g., the eastern NCC), while others retain them (e.g., the western NCC, Yilgarn and Superior cratons).

Based on the comprehensive comparison of geological, geophysical and geochemical data between cratons which have lost their roots and cratons that preserve them, we obtain the following preliminary conclusions:

\section{(1) Subduction polarity has significant impacts on craton destruction;}

The subduction polarity of subducting plates, specifically whether they dip under or away from the craton, controls the water released to the SCLM and underlying mantle wedge, which hydroweakens the SCLM. Thus, the lithosphere of the interior of the craton may become pre-weakened for delamination or SCLM erosion. Therefore subduction polarity has great effects on craton destruction.

\section{(2) Convergence between plates can lead to marginal lithospheric thinning;}

All three cratons analyzed here experienced SCLM thinning beneath their margins; evidence indicates that the thinning is most likely caused by convergence between plates. But craton destruction is not always accompanied by lithospheric thinning, except for cratons that suffered subduction and collision from multiple sides (e.g., the eastern NCC).

\section{(3) Protection by weak zones around the craton.}

As soon as a craton is surrounded by weak zones (e.g., mobile belts or orogens), the stresses

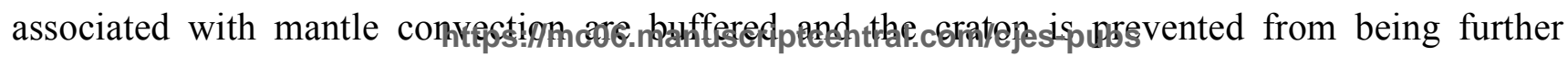


deformed, which reflects a general phenomenon and pattern in the evolution of craton.

\section{Acknowledgements}

We express gratitude to Kevin Burke and John F. Dewey for their landmark papers in tectonics, and for mentoring of the communicating author during his studies during the "golden years of tectonics" at the State University of New York at Albany. Kevin and John not only made fundamental contributions to understanding plate tectonics and the history of the Earth, but also mentored a new generation of tectonicists, many of whom are leaders in the field today. This study was financially supported by the National Natural Science Foundation of China (Nos. 91014002).

\section{References}

An, M., Shi, Y., 2006. Lithospheric thickness of the Chinese continent. Physics of the Earth and Planetary Interiors 159, 257-266.

Bagas, L., 2004. Proterozoic evolution and tectonic setting of the northwest Paterson Orogen, Western Australia. Precambrian Research 128, 475-496.

Badarch, G., Cunningham, W.D., Windley, B.F., 2002. A new terrane subdivision for Mongolia: Implications for the Phanerozoic crustal growth of central Asia. Journal of Asian Earth Sciences 21, 87-110,

Bao, X., Xu, M., Wang, L., Mi, N., Yu, D., Li, H., 2011. Lithospheric structure of the Ordos Block and its boundary areas inferred from Rayleigh wave dispersion. Tectonophysics 499, 132-141.

Barruol, G., Silver, P.G., Vauchez, A., 1997. A seismic anisotropy in the eastern United States: Deep structure of a complex continental plate. Journal of Geophysical Research 102, 8329-8348.

Bleeker, W., Ernst, R., 2006. Short-lived mantle generated magmatic events and their dyke swarms: the key unlocking Earth's palaeogeographic record back to 2.6 Ga. In: Hanski, E., Mertanen, S., Ramo, T., Vuollo, J. (Eds.), Dyke Swarms-Time Markers of Crustal Evolution. Taylor \& Francis, London, pp. 3-26.

Blewett, R.S., Henson, P.A., Roy, I.G., Champion, D.C., Cassidy, K.F., 2010. Scale-integrated architecture of a world-class gold mineral system: the Archaean eastern Yilgarn Craton, Western Australia. Precambrian Research 183, 230-250. 
Bodorkos, S., Clark, D.J., 2004. Evolution of a crustal-scale transpressive shear zone in the Albany Fraser Orogen, SW Australia: 2. Tectonic history of the Coramup Gneiss and a kinematic framework for Mesoproterozoic collision of the West Australian and Mawson cratons. Journal of Metamorphic Geology 22, 713-731.

Brown, S.J.A., Krapez, B, Beresford, S.W., Cassidy, K.F., Champion, D.C., Barley, M.E., Cas, R.A.F., 2001. Archaean volcanic and sedimentary environments of the Eastern Goldfields Province, Western Australia-a field guide. Western Australia Geological Survey Record, 2001/13.

Bruguier, O., Bosch, D., Pidgeon, R.T., Byrne, D.I., Harris, L.B., 1999. U-Pb chronology of the Northampton Complex, Western Australia-evidence for Grenvillean sedimentation, metamorphism and deformation and geodynamic implications. Contributions to Mineralogy and Petrology 136, 258-272.

Buchan, K.L., Ernst, R.E., 2004. Diabase dyke swarms and related units in Canada and adjacent regions. Geological Survey of CanadaMap2022A, withmap 1:5,000,000 and accompanying notes.

Burke, K.C., Dewey, J.F., and Kidd, W.S.F., 1976, Dominance of Horizontal Movements, Arc and Microcontinental Collision During the Later Permobile Regime, in: Windley, B.F., (ed.), The Early History of the Earth, Wiley, New York, p. 113-130.

Campbell, I.H., Hill, R.I., 1988. A two-stage model for the formation of the granitegreenstone terrains of the Kalgoorlie-Norseman area, Western Australia. Earth and Planetary Science Letters 90, 11-25.

Card, K.D., Poulsen, K.H., 1998. Geology and mineral deposits of the Superior Province of the Canadian Shield. Chapter 2 in Geological Survey of Canada, Geology of Canada, no. 7, pp. 13-194 (also Geological Society of America, The Geology of North

Chen, L., 2009. Lithospheric structure variations between the eastern and central North China Craton from S- and P-receiver function migration. Physics of the Earth and Plantetary / inc06. manuscriors $193,216-227$. 
Chen, L., 2010. Concordant structural variations from the surface to the base of the upper mantle in the North China Craton and its tectonic implications. Lithos 120, 96-115.

Clark, D.J., Hensen, B.J., Kinny, P.D., 2000. Geochronological constraints for a two-stage history of the Albany-Fraser Orogen,

Cobb, M.M., Cawood, P.A., Kinny, P.D., Fitzsimons, I.C.W., 2001. SHRIMP U-Pb zircon ages from the Mullingarra Complex, Western Australia: isotopic evidence for allochthonous blocks in the Pinjarra Orogen and implications for East Gondwana assembly.

Collins, A.S., 2003. Structure and age of the northern Leeuwin Complex, Western Australia: constraints from field mapping and $\mathrm{U}-\mathrm{Pb}$ analysis. Australian Journal of Earth Sciences 50, 585-599.

Collins, A.S., Pisarevsky, S.A., 2005. Amalgamating eastern Gondwana: the evolution of the Circum-Indian Orogens. Earth Science Reviews 71, 229-270.

Darbyshire, F.A., Lebedev, S., 2009. Rayleigh wave phase-velocity heterogeneity and multilayered azimuthal anisotropy of the

Darbyshire, F.A., Eaton, D.W., Bastow, I.D., 2013. Seismic imaging of the lithosphere beneath Hudson Bay: Episodic growth of the

Laurentian mantle keel. Earth and Planetary Science Letters 373, 179-193.

Davis, G.A., Qian, X.G., Zheng, Y.D., Tong, H.M., Yu, H., Wang, C., Gehrils, G., Shafiquallah, M., Fryxell, J., 1996. Mesozoic deformation and plutonism in the Yunmeng Shan: a metamorphic core complex north of Beijing, China, in: Yin, A., and Harrison,

T.M., The Tectonic Evolution of Asia. Cambridge University Press, 253-280.

Davis, G.A., Yadong, Z., Cong, W., Darby, B.J., Changhou, Z., Gehrels, G., 2001. Mesozoic tectonic evolution of the Yanshan fold and thrust belt, with emphasis on Hebei and Liaoning provinces, northern China. Memoirs-Geological Society of America, 171-198.

De Stefano, A., Lefebvre, N., Kopylova, M., 2006. Enigmatic diamonds in Archean calc-alkaline lamprophyres of Wawa, southern

De Boisgrollier, T., Petit, C., Fournier, M., Leturmy, P., Ringenbach, J.C., San'kov, V.A., Anisimova, S.A., Kovalenko, S.N., 2009.

Palaeozoic orogeneses around the Siberian craton: structure and evolution of the Patom belt and foredeep. Tectonics 28TC1005.

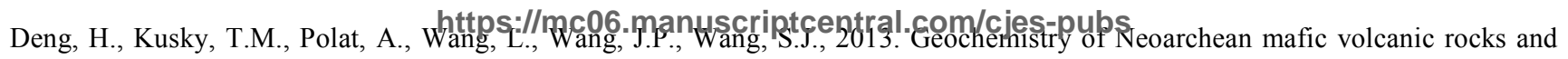


late mafic dikes in the Zanhuang Comples, Central Orogenic Belt, North China Craton: Implications for geodynamic setting. Lithos $175,193-212$.

Deng, J.F., Mo, X.X., Zhao, H.L., Wu, Z.X., Luo, Z.H., Su, S.G., 2004. A new model for the dynamic evolution of Chinese lithosphere: 'continental roots-plume tectonics'. Earth-Science Reviews 65, 223-275.

Deng, J.F., Su, S., Niu, Y., Liu, C., Zhao, G., Zhao, X., Wu, Z., 2007. A possible model for the lithospheric thinning of North China Craton: evidence from the Yanshanian (Jura-Cretaceous) magmatism and tectonism. Lithos 96, 22-35.

Dewey, J.F., and Burke, K.C., 1973, Tibetan, Variscan, and Precambrian basement reactivation: products of continental collision, Journal of Geology 81, 683-692.

Drury, M., Taylor, A., 1987. Some new measurements of heat flow in the Superior Province of the Canadian shield. Canadian Journal of Earth Sciences 24, 1486-1489.

Eaton, D.W., Darbyshire, F., 2010. Lithospheric architecture and tectonic evolution of the Hudson Bay region. Tectonophysics 480, $1-22$.

Ernst, R. E., Buchan, K. L., Palmer, H. C., 1995. Giant dyke swarms: characteristics, distribution and geotectonic applications. Physics and chemistry of dykes. Balkema, Rotterdam, 3-21.

Ernst, R. E., 2014. Large igneous provinces. Cambridge University Press.

Evans, D.A.D., Halls, H.C., 2010. Restoring Proterozoic deformation within the Superior craton. Precambrian Research 183, 474-489.

Fan, W., and Menzies, M.A., 1992. Contribution of the lithospheric mantle to extension-related volcanics-geochemical evidence from Cenozoic basaltic rocks in Hainan Island and Leizhou Peninsula, southern China, in L. Ruoxin (ed.), Chronology and Geochemistry of Cenozoic Volcanic Rocks in China. Seismology Press, China. pp. 320-329.

Faure, S., Godey, S., Fallara, F., Trepanier, S., 2011. Seismic architecture of the Archean North American mantle and its relationship to diamondiferous kimberlite fields. Economic Geology 106, 223-240.

Ferguson, I.J., Craven, J.A., Kurtz, R.D., Boerner, D.E., Bailey, R.C., Wu, X., Norton, M., 2005. Geoelectric response of Archean lithosphere in the western Superior Province, central Canada. Physics of the Earth and Planetary Interiors 150, $123-143$.

Fichtner, A., Kennett, B.L., Igel, H., Bunge, H.P., 2009. Full seismic waveform tomography for upper-mantle structure in the Australasian region using adjoint methods. Geophysical Journal International 179, 1703-1725.

Fitzsimons, I.C.W., 2003. Proterozoic basement provinces of southern and southwestern Australia, and their correlation with Antarctica. Geological Society of London Special Publications, 206, pp. 93-130.

Fishwick, S., Kennett, B.L.N., Reading, A.M., 2005. Contrasts in lithospheric structure within the Australian craton-insights from surface wave tomography. Earth and Ptane: 
1

2

3

4

5

6

7

Fishwick, S., Reading, A.M., 2008. Anomalous lithosphere beneath the Proterozoic of western and central Australia: A record of continental collision and intraplate deformation? Precambrian Research 166, 111-121.

Fishwick, S., Rawlinson, N., 2012. 3-D structure of the Australian lithosphere from evolving seismic datasets. Australian Journal of Earth Sciences 59, 809-826.

Flower, M.F.J., Tamaki, K., Hoang, N., 1998. Mantle extrusion: a model for dispersed volcanism and DUPAL-like asthenosphere in east Asia and the western Pacific. In: Flower, M., Ching, S.L., Lo, C.H., Lee, T.Y. (Eds.), Mantle Dynamics and Plate Interactions in East Asia. AGU Geodynamics Series 27, 67-88.

Ford, H.A., Fischer, K.M., Abt, D.L., Rychert, C.A., Elkins-Tanton, L.T., 2010. The lithosphere-asthenosphere boundary and cratonic lithospheric layering beneath Australia from Sp wave imaging. Earth and Planetary Science Letters 300, 299-310.

Fouch, M.J., James, D.E., VanDecar, J.C., 2004. The Kaapvaal seismic group, mantle seismic structure beneath the Kaapvaal and Zimbabwe cratons. South African Journal of Geology 107, 33-44.

Frederiksen, A.W., Miong, S.K., Darbyshire, F.A., Eaton, D.W., Rondenay, S., Sol, S., 2007. Lithospheric variations across the Superior Province, Ontario, Canada: Evidence from tomography and shear wave splitting. Journal of Geophysical Research: Solid Earth (1978-2012), 112(B7).

Gao, S., Rudnick, R., Carlson, R., McDonough, W., Liu, Y.S., 2002. Re-Os evidence for replacement of ancient mantle lithosphere beneath the North China craton. Earth and Planetary Science Letters 6135, 1-15.

Gao, S., Zhang, J.F., Xu, W.L., 2009. Delamination and destruction of the North China craton. China Science Bulletin 54, $3367-3378$.

Gee, R.D., 1979. Structure and tectonic style of the Western Australian Shield. Tectonophysics 58, 327-369.

Giles, D., Betts, P.G., Lister, G.S., 2004. 1.8-1.5 Ga links between the North and South Australian Cratons and the early-middle Proterozoic configuration of Australia. Tectonophysics 380, 27-41.

Godey, S., Deschamps, F., Trampert, J., 2004. Thermal and compositional anomalies beneath the North American continent. Journal of Geophysical Research 109, B01308. doi:10.1029/2002JB002263.

Goleby, B.R., Blewett, R. S., Fomin, T., Fishwick, S., Reading, A. M., Henson, P. A., Nicoll, M., 2006. An integrated multi-scale 3D seismic model of the Archaean Yilgarn Craton, Australia. Tectonophysics 420, 75-90.

Gordon, M.B., Hempton, M.R., 1986. Collision-induced rifting: The Grenville orogeny and the Keweenawan rift of North America. Tectonophysics 127, 1-25.

Graham, S., Lambert, D.D., Shee, S.R., Smith, C.B., Hamilton, R., 1999. Re-Os and Sm-Nd Isotopic Constraints on the Sources of Kimberlites and Melnoites, Earaheedy Basin, Western Australia. In: Gurney, J.J., Gurney, J.L., Pascoe, M.D., Richardson, S.H. (Eds.), 7th International Kimberlite Conference, Cape Town, Proceedings. Red Roof Design, Cape Town, pp. $280-290$. https://mc06.manuscriptcentral.com/cjes-pubs 
Graham, S., Lambert, D., Shee, S., 2004. The petrogenesis of carbonatite, melnoite and kimberlite from the Eastern Goldfields Province, Yilgarn Craton. Lithos 76, 519-533.

Gregersen, S., Voss, P., Nielsen, L.V., 2010. Uniqueness of modeling results from teleseismic P-wave tomography in Project Tor. Tectonophysics 481, 99-107.

Griffin, W.L., O'Reilly, S.Y., Ryan, C.G., 1992. Composition and thermal structure of the lithosphere beneath South Africa, Siberia and China: proton microprobe studies. In International Symposium on Cenozoic Volcanic rocks and deep-seated xenoliths of China and its Environs, Beijing (pp. 65-66).

Griffin, W.L., Andi, Z., O'reilly, S.Y., Ryan, C.G., 1998. Phanerozoic evolution of the lithosphere beneath the Sino - Korean craton. Mantle dynamics and plate interactions in East Asia, 107-126.

Griffin, W.L., Belousova, E.A., Shee, S.R., Pearson, N.J., O'reilly, S.Y., 2004a. Archean crustal evolution in the northern Yilgarn Craton: U-Pb and Hf-isotope evidence from detrital zircons. Precambrian Research 131, 231-282.

Griffin, W.L., O’Reilly. S,Y., Doyle, B.J., Pearson, N.J., Coopersmith, H., Kivi, K., Malkovets, V., Pokhilenko, N., 2004b. Lithospheric mapping beneath the North American plate. Lithos 77, 873-922.

Guo, J.H., Sun, M., Chen, F.K., Zhai, M.G., 2005. Sm-Nd and SHRIMP U-Pb zircon geochronology of high-pressure granulites in the Sanggan area, North China Craton: timing of Paleoproterozoic continental collision. Journal of Asian Earth Sciences 24, 629-642.

Hacker, B.R.L., Ratschbacher, L., Webb, M.O., McWilliams, T., Ireland, A., Calvert, S.W., Dong, H.R., Wenk, D., Chateigner, 2000. Exhumation of ultrahigh-pressure continental crust in east central China: Late Triassic-Early Jurassic tectonic unroofing. Journal of Geophysical Research-Solid Earth 105 (B6), 13339-13364.

Hacker, B.R., Wallis, S.R., McWilliams, M.O., Gans, P.B., 2009. 40Ar/39Ar constraints on the tectonic history and architecture of the ultrahigh-pressure Sulu orogen. Journal of Metamorphic Geology 27, 827-844.

Hall, L., Gibbons, A. D., Bernardel, G., Whittaker, J. M., Nicholson, C., Rollet, N., Müller, R. D., 2013. Structural architecture of Australia's southwest continental margin and implications for Early Cretaceous basin evolution. West Australian Basins Symposium. Petroleum Exploration Society of Australia (pp. 18-21).

Harman, R., Gallagher, K., Brown, R., Raza, A., Bizzi, L., 1998. Accelerated denudation and tectonic-geomorphic reactivation of the cratons of northeastern Brazil during the Late Cretaceous. Journal of Geophysical Research 103, 27091-27105.

Harrison, T. M., Blichert-Toft, J., Müller, W., Albarede, F., Holden, P., Mojzsis, S. J., 2005. Heterogeneous Hadean hafnium: evidence of continental crust at 4.4 to $4.5 \mathrm{Ga}$. Science $310,1947-1950$.

He, L., 2015. Thermal regime of the North China Craton: Implications for craton destruction. Earth-Science Reviews 140, 14-26.

Heaman, L.M., Kjarsgaard, B.A., 2000. Timing of eastern North American kimberlite magmatism: continental extension of the Great Meteor hotspot track? Earth and Planetary Science Letters 178, 253-268.

https://mc06.manuscriptcentral.com/cjes-pubs

$44 / 58$ 
Heaman, L.M, Kjarsgaard, B.A., Creaser, R.A., 2004. The temporal evolution of North American kimberlites. Lithos 76, $377-397$.

Hill, R.I., Chappell, B.W., and Campbell, I.H., 1992. Late Archaean granites of the southeastern Yilgarn Block, Western Australia; age, geochemistry, and origin. Special Paper-Geological Society of America 272, 211-226.

Hirth, G., Kohlstedt, D. L., 1996. Water in the oceanic upper mantle: implications for rheology, melt extraction and the evolution of the lithosphere. Earth and Planetary Science Letters 144, 93-108.

Hoffman, P.F., 1988. United Plates of America, the birth of a craton: early Proterozoic assembly and growth of Laurentia. Annual Review of Earth and Planetary Sciences 16, 543-603.

Holdsworth, R.E., Bulter, C.A., Roberts, A.M., 1997. The recognition of reactivation during continental deformation. Journal of the Geological Society of London 154, pp. 73-78.

Hu, S., He, L., Wang, J., 2000. Heat flow in the continental area of China: a new data set. Earth and Planetary Science Letters 179 , 407-419.

Huang, J., Zhao, D., 2006. High-resolution mantle tomography of China and surrounding regions. Journal of Geophysical Research 111, B09305. doi:10.1029/2005JB004066.

Huang, Z., Li, H., Zheng, Y., Peng, Y., 2009. The lithosphere of North China Craton from surface wave tomography. Earth and Planetary Science Letters 288, 164-173.

Huston, D.L., Blewett, R. S., Champion, D. C., 2012. Australia through time: a summary of its tectonic and metallogenic evolution. Episodes-Newsmagazine of the International Union of Geological Sciences 35, 23-43.

James, D.E., Fouch, M.J., VanDecar, J.C. and van der Lee, S., 2001. Tectospheric structure beneath southern Africa. Geophysical Research Letters 28, 2485-2488.

Jaques, A.L., Milligan, P.R., 2004. Patterns and controls on the distribution of diamondiferous intrusions in Australia. Lithos 77, $783-802$.

Jaupart, C., Mareschal, J.C., 2005. Production from Heat Flow Data. The Crust 3, 65-84.

Jiang, M.M., Ai, Y., Chen, L., Yang, Y., 2013. Local modification of the lithosphere beneath the central and western North China Craton: 3-D constraints from Rayleigh wave tomography. Gondwana Research 24, 849-864.

Kaminsky, F.V., Sablukov, S.M., Sablukova, L.I., Shchukin, V.S., Canil, D., 2002. Kimberlites from the Wawa area, Ontario. Canadian Journal of Earth Sciences 39, 1819-1838.

Karato, S., 1986. Does partial melting reduce the creep strength of the upper mantle? Nature 319, 309-310.

Kendall, J.M., Sol, S., Thomson, C.J., White, D.J., Asudeh, I., Snell, C.S., Sutherland, F.H., 2002. Seismic heterogeneity and anisotropy in the Western Superior Province, Canada: insights into the evolution of anj Archeans craton. In: Fowler CMR, Ebinger CJ, 
Hawkesworth CJ (eds) The early earth: physical, chemical, and biological development. Geological Society of London Special Publications, 199, pp. 27-44.

Kennett, B.L., Blewett, R.S., 2012. Lithospheric framework of Australia. Episodes-Newsmagazine of the International Union of

Keranen, K., Klemperer, S.L., 2008. Discontinuous and diachronous evolution of the Main Ethiopian Rift: implications for development of continental rifts. Earth and Planetary Science Letters 265, 96-111.

Kirkland, C.L., Spaggiari, C.V., Pawley, M.J., Wingate, M.T.D., Smithies, R.H., Howard, H.M., Tyler, I.M., Belousova, E.A. and

Poujol, M., 2011. On the edge: U-Pb, Lu-Hf, and Sm-Nd data suggest reworking of the Yilgarn craton margin during formation of the

Albany-Fraser Orogen. Precambrian Research 187, 223-247.

Komiya, T., Maruyama, S., 2007. A very hydrous mantle under the western Pacific region: implications for formation of marginal

basins and style of Archean plate tectonics. Gondwana Research 11, 132-147.

Krapež, B., Brown, S.J.A., Hand, J., Barley, M.E., Cas, R.A.F., 2000. Age constraints on recycled crustal and supracrustal sources of

Archaean metasedimentary sequences, Eastern Goldfields Province, Western Australia, Evidence from SHRIMP zircon dating.

Tectonophysics 322, 89-133.

Kröner, A., Wilde, S. A., Li, J. H., Wang, K. Y., 2005. Age and evolution of a late Archean to Paleoproterozoic upper to lower crustal section in the Wutaishan/Hengshan/Fuping terrain of northern China. Journal of Asian Earth Sciences 24, 577-595.

Kravchinsky, V.A., Cogne, J.P., Harbert, W.P., Kuzmin, M.I., 2002. Evolution of the Mongol-Okhotsk ocean as constrained by new paleomagnetic data from the Mongol-Okhotsk suture zone, Siberia. Geophysical Journal International 148, 34-57.

Kusky, T.M., Polat, A., 1999. Growth of Granite-Greenstone Terranes at Convergent Margins and Stabilization of Archean Cratons.

Tectonophysics 305, 43-73.

Kusky, T.M., Li, J.H., 2003. Paleoproterozoic tectonic evolution of the North China Craton. Journal of Asian Earth Sciences 22, 383-397.

Kusky, T.M., Windley, B.F., Zhai, M.G. 2007a. Tectonic evolution of the North China Block: from orogen to craton to orogen.

Kusky, T.M., Windley, B.F., Zhai, M.G., 2007b. Lithospheric thinning in eastern Asia; constraints, evolution, and tests of models. in:

Zhai. M.G., Windley, B.F., Kusky, T.M., Meng, Q.R. (Eds.), Mesozoic Sub-Continental Lithospheric Thinning under Eastern Asia.

Kusky, T.M., Li, J.H., Santosh, M., 2007c. The Paleoproterozoic North Hebei Orogen: North China craton's collisional suture with

Kusky, T.M., Santosh, M., 2009. The Columbia Connection in North China, in Reddy, S.M., Mazumder, R., Evans, D., and Collins, A.S., Paleoproterozoic Supercontinents and 
1

2 3

4 5 6

Kusky, T.M., 2011. Geophysical and geological tests of tectonic models of the North China Craton. Gondwana Research $20,26-35$.

Kusky, T.M., Zhai, M.G., 2012. The Neoarchean ophiolite in the North China Craton: Early Precambrian plate tectonics and scientific debate. Journal of Earth Sciences 23, 277-284.

Kusky, T.M., Li, X.Y., Wang, Z.S., 2014a. Are Wilson Cycles preserved in Archean cratons? A comparison of the North China and Slave cratons. Canadian Journal of Earth Sciences 51, 1-15.

Kusky, T.M., Windley, B.F., Wang, L., Wang, Z.S., Li, X.Y., Zhu, P.M., 2014b. Flat Slab Subduction, Trench Suction, and Craton Destruction: Comparison of the North China, Wyoming, and Brazilian Cratons. Tectonophysics 630, 208-221.

Kusky, T.M., Mooney, W.D., 2015. Is the Ordos Basin floored by a trapped oceanic plateau? Earth and Planetary Science Letters 429, 197-204.

Lenardic, A., Moresi, L.N, Mühlhaus, H., 2000. The role of mobile belts for the longevity of deep cratonic lithosphere: the crumple zone model. Geophysical Research Letters 27, 1235-1238.

Lenardic, A., Moresi, L.N., Mühlhaus, H., 2003. Longevity and stability of cratonic lithosphere: insights from numerical simulations of coupled mantle convection and continental tectonics. Journal of Geophysical Research: Solid Earth (1978-2012), 108(B6).

Lesne, O., Calais, E., Deverchère, J., Chéry, J., Hassani, R., 2000. Dynamics of intracontinental extension in the north Baikal rift from two-dimensional numerical deformation modeling. Journal of Geophysical Research: Solid Earth (1978-2012), 105(B9), $21727-21744$.

Li, C., van de Hilst, R.D., 2010. Structure of the upper mantle and transition zone beneath Southeast Asia from traveltime tomography. Journal of Geophysical Research 115, B07308, http://dx.doi.org/10.1029/2009JB006882.

Li, S., Mooney, W.D., Fan, J., 2006. Crustal structure of mainland China from deep seismic sounding data. Tectonophysics 420, 239-252.

Li, S.G., Xiao, Y.L., Liu, D.L., Chen, Y.Z., Ge, N.J., Zhang, Z.Q., Sun, S.S., Cong, B.L., Zhang, R.Y., Hart, S.R., Wang, S.S., 1993. Collision of the North China and Yangtze Blocks and formation of coesite-bearing eclogites - Timing and processes. Chemical Geology 109, 89-111.

Li, X.H., Su, L., Song, B., Liu, D.Y., 2004. SHRIMP U-Pb zircon age of the Jinchuan ultramafic intrusion and its geological significance. Chinese Science Bulletin 49, 420-422.

Li, Y., Wu, Q., Zhang, R., Pan, J., Zhang, F., Zeng, R., 2009. The lithospheric thinning of the North China Craton inferred from Rayleigh waves inversion. Geophysical Journal International 177, 1334-1342.

Li, Z.X., 1994. Collision between the North and South China blocks : a crustal detachment model for suturing in the region east of the Tan-Lu fault. Geology 22, 739-742. 
Li, Z.X., 1998. Tectonic history of the major East Asian Lithospheric Blocks since the mid-Proterozoic - a synthesis. In: Flowrr, M., Ching, S.L., Lo, C.H., Lee, T.Y. (Eds.), Mantle Dynamics and Plate Interactions in East Asia. AGU Geodynamics Series, vol. 27, pp. 221-243.

Ligeos, J.P., Abdesalam, M.G., Ennih, N., Ouabadi, A., 2012. Metacraton: nature, genesis and behavior. Gondwana Research 23, 220-237.

Liu, D.Y., Nutman, A.P., Compston, W., Wu, J.S., Shen, Q.H., 1992. Remnants of $>=3800$ Ma crust in the Chinese part of the Sino-Korean craton. Geology 20, 339-342.

Liu, J., Han, J., and Fyfe, W.S., 2001. Cenozoic episodic volcanism and continental rifting in northeast China and possible link to Japan Sea development as revealed from K-Ar geochronology. Tectonophysics 339, 385-401.

Liu, Y., Gao, S., Hu, Z., Gao, C., Zong, K., Wang, D., 2009. Continental and oceanic crust recycling-induced melt-peridotite interactions in the Trans-North China Orogen: U-Pb dating, $\mathrm{Hf}$ isotopes and trace elements in zircons from mantle xenoliths. Journal of Petrology, egp082.

Liu, Y.C., Wang, A.D., Li, S.G., Rolfo, F., Li, Y., Groppo, C., Hou, Z.H., 2013. Composition and geochronology of the deep-seated xenoliths from the southeastern margin of the North China Craton. Gondwana Research 23, 1021-1039.

Lu, G., Kaus, B.J., Zhao, L., 2011. Thermal localization as a potential mechanism to rift cratons. Physics of the Earth and Planetary Interiors 186, 125-137.

Ludden, J., and Hynes, A., 2000. The lithoprobe Abitibi-Grenville transect: Two billion years of crust formation and recycling in the Precambrian Shield of Canada. Canadian Journal of Earth Sciences 37, 459-476.

Ma, X., Liu, G., and Su, J., 1984. The structure and dynamics of the continental lithosphere in north-northeast China. Annales

Geophysicae 2, 611-620.

Ma, X., and Wu, D., 1987. Cenozoic extensional tectonics in China. Tectonophysics 133, 243-255.

Mareschal, J.C., Jaupart, C., 2004. Variations of surface heat flow and lithospheric thermal structure beneath the North American craton. Earth and Planetary Science Letters 223, 65-77.

Maruyama, S., Okamoto, K., 2007. Water transportation from the subducting slab into the mantle transition zone. Gondwana

Maruyama, S., Yuen, D.A., Windley, B.F., 2007a. Dynamics of plumes and superplumes through time. in: Yuen, D.A., Maruyama, S.,

Karato, S.I., Windley, B.F. (Eds.), Superplumes: Beyond Plate Tectonics. Springer, Dordrecht, pp. 441-502.

Menzies, M.A., Fan, W., Zhang, M., 1993. Palaeozoic and Cenozoic lithoprobes and the loss of $>120 \mathrm{~km}$ of Archaean lithosphere, 
$155-165$.

2

Meng, Q.R., Zhang, G.W., 2000. Geologic framework and tectonic evolution of the qinling orogen, central China. Tectonophysics 323, 183-196.

Meyer, H.O.A., Waldman, M.A., Garwood, B.L., 1994. Mantle xenoliths from kimberlite near Kirkland Lake, Ontario. Canadian Mineralogist 32, 295-306.

Miller, C.E., Kopylova, M.G., Ryder, J., 2012. Vanished diamondiferous cratonic root beneath the Southern Superior province: evidence from diamond inclusions in the Wawa metaconglomerate. Contributions to Mineralogy and Petrology 164, 697-714.

Mole, D.R., Fiorentini, M.L., Thebaud, N., McCuaig, T.C., Cassidy, K F., Kirkland, C.L., Belousova, E.A., 2012. Spatio-temporal constraints on lithospheric development in the southwest-central Yilgarn Craton, Western Australia. Australian Journal of Earth Sciences 59, 625-656.

Morgan, P., 1984. The thermal structure and thermal evolution of the continental lithosphere. In: H.N. Pollack and V.R. Murthy (Editors), Structure and Evolution of the Continental Lithosphere. Physics and Chemistry of the Earth 15, 107-193.

Moser, D.E., Heaman, L.M., 1997. Proterozoic zircon growth in Archean lower crustal xenoliths, southern Superior craton-a consequence of Matachewan ocean opening. Contributions to Mineralogy and Petrology 128, 164-175.

Musashino, M., 1990. The Panthalassa-a cerium-rich Atlantic-type ocean: sedimentary environments of the Tamba Group, Southwest Japan. Tectonophysics 181, 165-177.

Myers, J.S., 1990. Precambrian tectonic evolution of part of Gondwana, southwestern Australia. Geology 18, 537-540.

Myers, J.S., 1993. Precambrian history of the West Australian craton and adjacent orogens. Annual Review of Earth and Planetary Sciences $21,453-485$.

Myers, J.S., 1995. The generation and assembly of an Archaean supercontinent. Evidence from the Yilgarn craton, Western Australia. In: Coward, M.P., and Ries, A.C. (eds), Early Precambrian Processes. Geological Society Special Publication, 95, pp. 143-154.

Myers, J.S., Shaw, R.D., Tyler, I.M., 1996. Tectonic evolution of Proterozoic Australia. Tectonics 15, 1431-1446.

Nemchin, A.A., Pidgeon, R.T., 1997. Evolution of the Darling range batholith, Yilgarn craton, western Australia: a SHRIMP zircon study. Journal of Petrology 38, 625-649.

Niu, Y.L., 2005. Generation and evolution of basaltic magmas: Some basic concepts and a hypothesis for the origin of the Mesozoic-Cenozoic volcanism in eastern China. Geological Journal of China Universities 11, 9-46.

Norvick, M.S., Smith, M.A., 2001. Mapping the plate tectonic reconstruction of Southern and Southeastern Australia and implications for petroleum systems. APPEA Journal-Australian Petroleum Production and Exploration Association 41, 15-35.

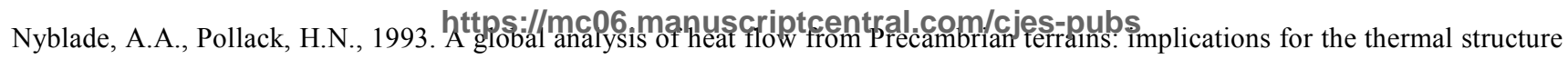


of Archean and Proterozoic lithosphere. Journal of Geophysical Research 98, 12207-12218.

Peacock S. M., 1993. The importance of blueschist $\rightarrow$ eclogite dehydration reactions in subducting oceanic crust. Geological Society of America Bulletin 105, 684-694.

Percival, J.A., McGrath, H., 1986. Deep crustal structure and tectonic history of the northern Kapuskasing uplift of Ontario: an integrated petrological-geophysical study. Tectonics 5, 553-572.

Percival, J.A., Peterman, Z.E., 1994. Rb-Sr biotite and whole-rock data from the Kapuskasing uplift and their bearing on the cooling and exhumation history. Canadian Journal of Earth Sciences 31, 1172-1181.

Occhipinti, S.A., Sheppard, S., Passchier, C., Tyler, I.M., Nelson, D.R., 2004. Palaeoproterozoic crustal accretion and collision in the southern Capricorn Orogen: the Glenburgh Orogeny. Precambrian Research 128, 237-255.

Oh, Chang Whan, Kusky Timothy, 2007. The Late-Permian to Triassic Hongseong-Odesan Collision belt in South Korea and its Tectonic correlation with Korea, China and Japan International Geology Review, v. 49, no 7., 636-657, DOI: 10.2747/0020-6814.49.7.636.

Percival, J.A, Sanborn-Barrie, M., Skulski, T., Stott, G.M., Helmstaedt, H., White, D.J., 2006. Tectonic evolution of the western Superior Province from NATMAP and Lithoprobe studies. Canadian Journal of Earth Sciences 43, 1085-1117.

Pearson, D.G., Meyer, H.O.A., Boyd, F.R., Shirey, S.B., Carlson, R.W., 1997. Re-Os isotope evidence for late Archaean stabilisation of a thick lithospheric mantle keel beneath the Kirkland Lake area, Superior Province, Canada. Further evidence for long-term crust-mantle coupling. Russian geology and geophysics, special issue: proceedings of the 6th International Kimberlite Conference, vol 2, pp 427-429.

Peng, P., Wang, X., Windley, B. F., Guo, J., Zhai, M., Li, Y., 2014. Spatial distribution of 1950-1800Ma metamorphic events in the North China Craton: Implications for tectonic subdivision of the craton. Lithos 202, 250-266.

Perry, H.K.C., Mareschal, J.C., Jaupart, C., 2006. Variations of strength and localized deformation in cratons: the 1.9 Ga Kapuskasing uplift, Superior Province, Canada. Earth and Planetary Science Letters 249, 216-228.

Perry, H.K.C., Jaupart, C., Mareschal, J. C., Bienfait, G., 2006b. Crustal heat production in the Superior Province, Canadian Shield, and in North America inferred from heat flow data. Journal of Geophysical Research, 111(B4).

Pisarevsky, S.A., Wingate, M.T.D., Powell, C.M.A., Johnson, S., Evans, D.A.D., 2003. Models of Rodinia assembly and fragmentation, in Proterozoic East Gondwana: supercontinent assembly and breakup, in Yoshida, M., Windley, B.F., Dasgupta, S., (Eds), Proterozoic East Gondwana: supercontinent assembly and breakup. Geological Society of London Special Publication, 206, pp. $35-55$.

Queen, M., Heaman, L.M., Hanes, J.A., Archibald, D.A., Farrar, E., 1996. 40Ar/39Ar phlogopite and U-Pb perovskite dating of lamprophyre dykes from the eastern Lake Superior region: evidence for a $1.14 \mathrm{Ga}$ magmatic precursor to Midcontinent Rift volcanism. Canadian Journal of Earth Sciences 33, 958-965.

https://mc06.manuscriptcentral.com/cjes-pubs 
Reading, A.M., Kennett, B.L.N., 2003. Lithospheric structure of the Pilbara Craton, Capricorn Orogen and northern Yilgarn Craton, Western Australia, from teleseismic receiver functions. Australian Journal of Earth Sciences 50, 439-445.

Robinson P.T., Zhou, M.F., Hu, X.F., Reynolds, P., Bai, W.J., Yang, J.S., 1999. Geochemical constraints on the origin of the Hegenshan ophiolite, Inner Mongolia, China. Journal of Asian Earth Sciences 17, 423-442.

Rogers, J.J.W., Santosh, M., 2002. Configuration of Columbia, a Mesoproterozoic Supercontinent. Gonwana Research 5, 5-22.

Rolandone, F., Mareschal, J.C., Jaupart, C., Gosselin, C., Bienfait, G., Lapointe, R., 2003. Heat flow in the western Superior Province of the Canadian shield. Geophysical Research Letters 30, 1637-1640.

Sage, R.P., 2000. Kimberlites of the Lake Timiskaming structural zone. Open File Rep. Ontario Geological Survey, 6018.

Sandu, C., Lenardic, A., O'Neill, C., Cooper, C.M., 2011. Earth's evolving stress state and the past, present, and future stability of cratonic lithosphere. International Geology Review 53, 1392-1402.

Santosh, M., Zhao, D.P., Kusky, T.M., 2010. Mantle dynamics of the Paleoproterozoic North China Craton: a perspective based on seismic tomography. Journal of Geodynamics 49, 39-53.

Schneider, D.A., Heizler, M.T., Bickford, M.E., Wortman, G.L., Condie, K.C., Perilli, S., 2007. Timing constraints of orogeny to cratonization: Thermochronology of the Paleoproterozoic Trans-Hudson orogen, Manitoba and Saskatchewan, Canada. Precambrian Research 153, 65-95.

Schulz, K.J., Cannon, W.F., 2007. The Penokean orogeny in the Lake Superior region. Precambrian Research 157, 4-25.

Scully, K.R., Canil, D., Schulze, D.J., 2004. The lithospheric mantle of the Archean Superior Province as imaged by garnet xenocryst geochemistry. Chemical Geology 207, 189-221.

Sengör, A.M.C., and Burke, K., 1978. Relative timing of rifting and volcanism on earth and its tectonic implications. Geophysical Research Letters 5, 419-421.

Sengör, A.M.C., 1985. East Asia tectonic collage. Nature 318, 16-17.

Sengör, A.M.C., 1999. Continental interiors and cratons: any relation? Tectonophysics 305, 1-42.

Shapiro, S.S., Hager, B.H., Jordan, T.H., 1999. Stability and dynamics of the continental tectosphere. Lithos 48, 1-4.

Shee, S.R., Vercoe, S.C., Wyatt, B.A., Hwang, P.H., Campbell, A.N., Colgan, E.A., 1999. Discovery and geology of the Nabberu Kimberlite Province, Western Australia. In: Gurney, J.J., Gurney, J.L., Pascoe, M.D., Richardson, S.H. (Eds.), 7th International Kimberlite Conference, Cape Town, Proceedings. Red Roof Design, Cape Town, pp. 912-922.

Simons, F.J., Zielhuis, A., van der Hilst, R.D., 1999. The deep structure of the Australian continent from surface wave tomography. Developments in Geotectonics 24, 17-43. 
Simons, F.J., van der Hilst, R.D., Montagner, J.P., Zielhuis, A., 2002. Multimode Rayleigh wave inversion for heterogeneity and azimuthal anisotropy of the Australian upper mantle. Geophysical Journal International 151, 738-754.

Sleep, N.H., 2005. Evolution of the continental lithosphere. Annual Review of Earth and Planetary Sciences 33, $369-393$.

Smith, E.M., Kopylova, M.G., Nowell, G.M., Pearson, D.G., Ryder, J., 2012. Archean mantle fluids preserved in fibrous diamonds from Wawa, Superior craton. Geology 40, 1071-1074.

Smit, K.V., Stachel, T., Stern, R.A., 2014. Diamonds in the Attawapiskat area of the Superior craton (Canada): evidence for a major diamond-forming event younger than 1.1 Ga. Contributions to Mineralogy and Petrology 167, 1-16.

Smithies, R.H., Howard, H.M., Evins, P.M., Kirkland, C.L., Kelsey, D.E., Hand, H., Wingate, M.T.D., Collins, A.S., Belousova, E. and Allchurch, S., 2010. Geochemistry, geochronology and petrogenesis of Mesoproterozoic felsic rocks in the western Musgrave Province of central Australia, and implications for the Mesoproterozoic tectonic evolution of the region. Geological Survey of Western Australia, Report 106, pp. 73.

Sol, S., Thomson, C.J., Kendall, J.M., White, D., VanDecar, J.C., Asudeh, I., 2002. Seismic tomographic images of the cratonic upper mantle beneath the Western Superior Province of the Canadian Shield-a remnant Archean slab? Physics of the Earth and Planetary Interiors 134, 53-69.

Stachel, T., Banas, A., Muehlenbachs, K., Kurszlaukis, S., Walker, E.C., 2006. Archean diamonds from Wawa (Canada): samples from deep cratonic roots predating cratonization of the Superior Province. Contributions to Mineralogy and Petrology 151, 737-750.

Swager C.P., 1997. Tectono-stratigraphy of late Archaean greenstone terranes in the southern Eastern Goldfields, Western Australia. Precambrian Research 83, 11-42.

Thurston, P.C., Williams, H.R., Sutcliffe, R.H., Stott, G.M., (eds.), 1991. Geology of Ontario. Ontario Geological Survey Special 4, pp. 3-25.

Thurston, P.C., 2002. Autochthonous development of Superior Province greenstone belts? Precambrian Research 115, 11-36.

Tohver, E., Bettencourt, J. S., Tosdal, R., Mezger, K., Leite, W. B., Payolla, B. L., 2004. Terrane transfer during the Grenville orogeny: tracing the Amazonian ancestry of southern Appalachian basement through $\mathrm{Pb}$ and $\mathrm{Nd}$ isotopes. Earth and $\mathrm{Planetary}$ Science Letters 228, 161-176.

Tohver, E., Van der Pluijm, B.A., Mezger, K., Scandolara, J. E., Essene, E. J., 2005. Two stage tectonic history of the SW Amazon craton in the late Mesoproterozoic: identifying a cryptic suture zone. Precambrian Research 137, 35-59.

Tomurtogoo, O., Windley, B.F., Kröner, A., Badarch, G., Liu, D.Y., 2005. Zircon age and occurrence of the Adaatsag ophiolite and Muron shear zone, central Mongolia: constraints on the evolution of the Mongol-Okhotsk ocean, suture and orogen. Journal of the Geological Society 162, 125-134.

Tyler, I.M., Hocking, R.M., 2001. Tectonic units of Western Australia (scale 1:2, 500,000), Western Australia Geological Survey. https://mc06.manuscriptcentral.com/cjes-pubs 
van der Lee, S., Frederiksen, A., 2005. Surface wave tomography applied to the North American upper mantle. Geophysical Monograph Series 157, 67-80.

Van Gerven, L., Deschamps, F., van der Hilst, R.D., 2004. Geophysical evidence for chemical variations in the Australian Continental Mantle. Geophysical Research Letters 31, L17607, doi:10.1029/2004GL020307.

Veevers, J.J., 2006. Updated Gondwana (Permian-Cretaceous) earth history of Australia. Gondwana Research 9, 231-260.

Vicker, P.A., 1997. Garnet peridotite xenoliths from kimberlite near Kirkland Lake, Canada. MSc Thesis, University of Toronto.

Wang, C.Y., Sandvol, E., Zhu, L., Lou, H., Yao, Z., Luo, X., 2014. Lateral variation of crustal structure in the Ordos block and surrounding regions, North China, and its tectonic implications. Earth and Planetary Science Letters 387, 198-211.

Wang, J.P., Kusky, T.M., Polat, A., Wang, L., Deng, H., Wang, S.J., 2013. A late Archean tectonic mélange in the Central Orogenic Belt, North China Craton. Tectonophysics 608, 929-946.

Wang, L., Jin, Z.M., Kusky, T.M., Xu, H.J., Liu, X.W., 2010. Microfabric characteristics and rheological significance of ultra-high-pressure metamorphosed jadeite-quartzite and eclogite from Shuanghe, Dabie Mountains, China. Journal of Metamorphic Geology 28, 163-182.

Wang, L., Kusky, T.M., Polat, A., Wang, S.J., Jiang, X.F., Zong, K.Q., Wang, J.P., Deng, H., Fu, J.M., 2014. Partial melting of deeply subducted eclogite from the Sulu orogen in China. Nature Communications, DOI: 10.1038/ncomms6604.

Wang, X., Fang, J., Hsu, H., 2014. Three-dimensional density structure of the lithosphere beneath the North China Craton and the mechanisms of its destruction. Tectonophysics 610, 150-158.

Wang, X.C., Li, Z.X., Li, J., Pisarevsky, S.A., Wingate, M.T.D., 2014. Genesis of the 1.21 Ga Marnda Moorn large igneous province byplume-lithosphere interaction. Precambrian Research 241, 85- 103.

Wang, Y., 2001. Heat flow pattern and lateral variations of lithosphere strength in China mainland: constraints on active deformation. Physics of the Earth and Planetary Interiors 126, 121-146.

Wang, Y., Zhou, L., Zhao, L., 2013. Cratonic reactivation and orogeny: an example from the northern margin of the North China Craton. Gondwana Research 24, 1203-1222.

Weber, U.D., Kohn, B.P., Gleadow, A.J.W., Nelson, D.R., 2005. Low temperature Phanerozoic history of the Northern Yilgarn Craton, Western Australia. Tectonophysics 400, 127-151.

Wilde, S.A., Valley, J.W., Peck, W.H., Graham, C.M., 2001. Evidence from detrital zircons for the existence of continental crust and oceans on the Earth 4.4 Gyr ago. Nature 409, 175-178.

Wilde, S.A., Zhao, G., Sun, M., 2002. Development of the North China Craton during the late Archaean and its final amalgamation at 1.8 Ga: some speculations on its position within a global Palaeoproterozoic supercontinent. Gondwana Research 5, 85-94. https://mc06.manuscriptcentral.com/cjes-pubs 
Wilde, S.A., Zhou, X., Nemchin, A.A., Sun, M., 2003. Mesozoic crustmantle interaction beneath the North China Craton: a consequence of the dispersal of Gondwanaland and accretion of Asia. Geology 31, 817-820.

Williams, H.R., 1990. Subprovince accretion tectonics in the south-central Superior Province. Canadian Journal of Earth Sciences, 27: 570-581.

Windley, B.F., 1995. The Evolving Continents, 3rd ed. John Wiley \& Sons, England,526 pp.

Windley, B. F., Alexeiev, D., Xiao, W., Kröner, A., Badarch, G., 2007. Tectonic models for accretion of the Central Asian Orogenic Belt. Journal of the Geological Society 164, 31-47.

Windley, B.F., Maruyama, S., Xiao, W.J., 2010. Delamination/thinning of sub-continental lithosphereic mantle under eastern China: the role of water and multiple subduction. American Journal of Science 910, 1250-1298.

Wu, F.Y., Walker, R.J., Ren, X.W., Sun, D.Y., Zhou, X.H., 2003. Osmium isotopic constraints on the age of lithospheric mantle beneath northeastern China. Chemical Geology 196, 107-129.

Wu, F.Y., Walker, R.J., Yang, Y.H., Yuan, H.L., Yang, J.H., 2006. The chemical-temporal evolution of lithospheric mantle underlying the North China Craton. Geochimica et Cosmochimica Acta 70, 5013-5034.

Wu, F.Y., Xu, Y.G., Gao, S., Zheng, J.P., 2008a. Controversial on studies of the lithospheric thinning and craton destruction of North China. Acta Petrologica Sinica 24, 1145-1174 (in Chinese with English abstract).

Wu, F.Y., Zhang, Y.B., Yang, J.H., Xie, L.W., Yang, Y.H., 2008b. Zircon U-Pb and Hf isotopic constraints on the Early Archean crustal evolution in Anshan of the North China Craton. Precambrian Research 167, 339-362.

Xiao, W.J., Windley, B.F., Hao, J., Zhai, M.G., 2003. Accretion leading to collision and the Permian Solonker suture, Inner Mongolia, China: termination of the Central Asian Orogenic Belt. Tectonics 22, 1069. doi:10.1029/2002TC001484.

Xiao, W.J., Windley, B.F., Huang, B.C., Han, C.M., Yuan, C., Chen, H.L., Sun, M., Sun, S., Li, J.L., 2009a. End Permian to mid-Triassic termination of the southern Central Asian Orogenic Belt. International Journal of Earth Sciences, 98, 1189-1217, Doi: 10.1007/s00531-008-0407-z.

Xiao, W.J., Kröner, A., Windley, B.F., 2009b. Geodynamic Evolution of Central Asia in the Paleozoic and Mesozoic. International Journal of Earth Sciences 98, 1185-1188.

Xiao, W.J., Li, S.Z., Santosh, M., Jahn, B.M., 2012. Orogenic Belts in Central Asia: Correlations and connections. Journal of Asian Earth Sciences 49, 1-6.

Xu, Y.G., 2001. Thermo-tectonic destruction of the Archaean lithospheric keel beneath the Sino-Korean Craton in China: Evidence, timing and mechanism. Physics and Chemistry of the Earth, Part A. Solid Earth and Geodesy 26, 747-757.

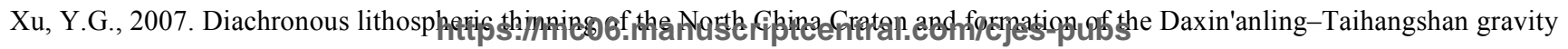




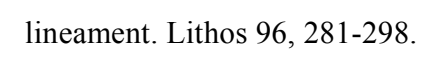

Xu, Z.G., 1990. Mesozoic volcanism and volcanogenic iron ore deposits in eastern China. Geological Society of America Special 4 Papers 237, 1-49.

5

Yang, W.C., 2003. Flat mantle reflectors in Eastern China: possible evidence of lithospheric thinning. Tectonophysics 369, $219-230$.

Ye, K., Cong, B.L., Ye, D.N., 2000. The possible subduction of continental materials to depths greater than $200 \mathrm{~km}$. Nature 407 , 334-336.

Yin, A., Harrison, T.M., 2001. Geologic evolution of the Himalayan-Tibetan orogen. Annual Review of Earth and Planetary Sciences $28,211-280$.

Yin, A. Nie, S. Y. 1993. An indentation model for the North and South China collision and the development of the Tanlu and Honam fault systems, eastern Asia.Tectonics, 12, 801-813.

Yin, A. Nie, S. Y. 1996. A Phanerozoic palinspastic reconstruction of China and its neighboring regions. In: YIN, A. \& HARRISON, T. M. (eds) The Tectonic Evolution of Asia. Cambridge University Press, Cambridge, 442-485.

Yoshida, M., 2012. Dynamic role of the rheological contrast between cratonic and oceanic lithospheres in the longevity of cratonic lithosphere: A three-dimensional numerical study. Tectonophysics 532, 156-166.

Yoshida, M., 2010. Preliminary three-dimensional model of mantle convection with deformable, mobile continental lithosphere. Earth and Planetary Science Letters 295, 205-218.

Yu, C.M., Zheng, J.P., Griffin, W.L., 2007. In situ Re-Os isotope ages of sulfides in Hannuoba peridotitic xenoliths: significance for the frequently-occurring mantle events beneath the North China Block. Chinese Science Bulletin 52, 2847-2853.

Yuan, H., Romanowicz, B., 2010. Lithospheric layering in the North American Craton. Nature 466, 1063-1068.

Yuan, X.C., 1996. Chief compiler, Atlas of Geophysics in China, Publ. No 201 of the Int. Lithosphere Program (Geological Publishing House, Beijing).

Zang, S.X., Wei, R.Q., Liu, Y.G., 2005. Three-dimensional rheological structure of the lithosphere in the Ordos block and its adjacent area. Geophysical Journal International 163, 339-356.

Zhai, M.G., Liu, W., 2005. Neoarchean to Paleoproterozoic continental evolution and tectonic history of the North China Craton: a review. Journal of Asian Earth Sciences 24, 547-561.

Zhai, M.G., Fan, Q.C., Zhang, H.F., Sui, J.L., Shao, J.A., 2007. Lower crustal processes leading to Mesozoic lithospheric thinning beneath eastern North China: Underplating, replacement and delamination. Lithos 96, 36-54.

Zhai, M.G., 2011. Cratonization and the Ancient North China Continent: A summary and review. Science China Earth Sciences 54, 1110-1120. https://mc06.manuscriptcentral.com/cjes-pubs 
Zhang, H.F., Sun, M., Zhou, X.H., Fan, W.M., Zhai, M.G., Yin, J.F., 2002. Mesozoic lithosphere destruction beneath the North China Craton: evidence from major, trace element, and $\mathrm{Sr}-\mathrm{Nd}-\mathrm{Pb}$ isotope studies of Fangcheng basalts. Contributions to Mineralogy and

Petrology 144, 241-253.

Zhang, H.F., Sun, M., Zhou, X.H., Zhou, M.F., Fan,W.M., Zheng, J.P., 2003. Secular evolution of the lithosphere beneath the eastern North China Craton: evidence from Mesozoic basalts and high-Mg andesites. Geochimica et Cosmochimica Acta 67, 4373-4387.

Zhang, H.F., Ying, JF., Tang, Y.J., Li, X.H., Feng, C., Santosh, M., 2011. Phanerozoic reactivation of the Archean North China Craton through episodic magmatism: evidence from zircon $\mathrm{U}-\mathrm{Pb}$ geochronology and $\mathrm{Hf}$ isotopes from the Liaodong Peninsula. Gondwana Research 19, 446-459.

Zhang, H.F., Yang, Y.H., Santosh, M., Zhao, X.M., Ying, J.F., Xiao, Y., 2012. Evolution of the Archean and Paleoproterozoic lower crust beneath the Trans-North China Orogen and the Western Block of the North China Craton. Gondwana Research 22, 73-85.

Zhang, S.H., Zhao, Y., Liu, J.M., Hu, J.M., Song, B., Liu, J., Wu, H., 2010. Geochronology, geochemistry and tectonic setting of the Et Mineralogica 29, 824-842 (in Chinese with English abstract).

Zhang, S.H., Zhao, Y., Davis, G.A., Ye, H., Wu, F., 2014. Temporal and spatial variations of Mesozoic magmatism and deformation in the North China Craton: Implications for lithospheric thinning and decratonization. Earth-Science Reviews 131, 49-87.

Zhang, Y.Q., Mercier, J.L., Vergely, P., 1998. Extension in the graben systems around the Ordos (China), and its contribution to the extrusion tectonics of south with respect to Gobi-Mongolia. Tectonophysics 285, 41-75.

Zhang, Z., Zhang, H., Shao, J. A., Ying, J., Yang, Y., Santosh, M., 2014. Mantle upwelling during Permian to Triassic in the northern

Zhao, Z.F., Zheng, Y.F., Wei, C.S., Wu, Y.B., 2004. Zircon isotope evidence for recycling of subducted continental crust in

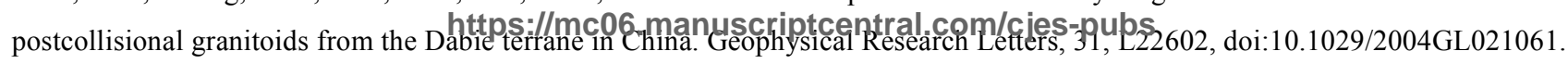


1

2

Zheng, J.P., O'reilly, S.Y., Griffin, W.L., Lu, F., Zhang, M., 1998. Nature and evolution of Cenozoic lithospheric mantle beneath Shandong peninsula, Sino-Korean craton, eastern China. International Geology Review 40, 471-499.

Zheng, J.P., Griffin, W.L., O'Reilly, S.Y., Lu, F., Wang, C., Zhang, M., Li, H., 2004. 3.6 Ga lower crust in central China: new evidence on the assembly of the North China Craton. Geology 32, 229-232.

Zheng, J.P., Sun, M., Zhou, M. F., Robinson, P., 2005. Trace elemental and PGE geochemical constraints of Mesozoic and Cenozoic peridotitic xenoliths on lithospheric evolution of the North China Craton. Geochimica et Cosmochimica Acta 69, 3401-3418.

Zheng, J.P., Griffin, W.L., O’Reilly, S.Y., Yang, J.S., Li, T.F., Zhang, M., Zhang, R.Y., Liou, J.G., 2006. Mineral chemistry of peridotites from Paleozoic, Mesozoic and Cenozoic lithosphere: constraints on mantle evolution beneath eastern China. Journal of Petrology 47, 2233-2256.

Zheng, J.P., Griffin, W.L., O’Reilly, S.Y., Yu, C.M., Zhang, H.F., Pearson, N., Zhang, M.. 2007. Mechanism and timing of lithospheric modification and replacement beneath the eastern North China Craton: peridotitic xenoliths from the 100 Ma Fuxin basalts and a regional synthesis. Geochimica et Cosmochimica Acta 71, 5203-5225.

Zheng, J.P., Griffin, W.L., O'Reilly, S.Y., Hu, B.Q., Zhang, M., Pearson, N., Wang, F.Z., Lu, F.X., 2008. Continental collision/accretion and modification recorded in the deep lithosphere of central China. Earth and Planetary Science Letters 269, 496-506.

Zheng, J.P., Griffin, W.L., Ma, Q., O'Reilly, S.Y., Xiong, Q., Tang, H.Y., Su, Y.P., 2012. Accretion and reworking beneath the North China Craton. Lithos 149, 61-78.

Zheng, Y.F., Wu, F.Y., 2009. Growth and reworking of cratonic lithosphere. Chinese Science Bulletin 54, $3347-3353$.

Zhu, R.X., Zheng, T.Y., 2009. Destruction geodynamics of the North China craton and its Paleoproterozoic plate tectonics. Chinese Science Bulletin 54, 3354-3366.

Zhu, R.X., Chen, L., Wu, F.Y., Liu, J., 2011. Timing, scale and mechanism of the destruction of the North China Craton. Science China Earth Sciences 54, 789-797.

Zhu, R.X., Xu, Y., Zhu, G., Zhang, H., Xia, Q., Zheng, T.Y., 2012. Destruction of the North China Craton. Science China Earth Sciences 55, 1565-1587.

Zorin, Y.A., Belichenko, V.G., Rutshtein, I.G., 1998. Geodynamics of the western part of the Mongolia-Okhotsk fold belt and tectonic framework of gold mineralization in the Transbaikalia area. Russian Geology and Geophysics 39, $1578-1586$.

Zorin, Y.A., 1999. Geodynamics of the western part of the Mongolia-Okhotsk collisional belt, Trans-Baikal region (Russia) and Mongolia. Tectonophysics 306, 33-56. 
Fig.1. (A) Schematic geological map of NCC and adjacent areas. (B) Simplified tectonic map of NCC (modified from Kusky et al. (2014a)). Numbers in rectangles are age information recorded by xenoliths (only presented data related with marginal lithospheric thinning), R means reworking. Xenoliths Data source: Zheng et al. 2004, 2005, 2012; Zheng and Wu 2009; Yu et al. 2007; Zhang et al. 2012; Liu et al. 2013. WNCC: Western part of the North China Craton (also known as the Ordos Block, e.g., OB); ENCC: Eastern part of the North China Craton; COB: Central Orogenic Belt; SSR, Shanxi-Shaanxi Rift; YHR, Yinchuan-Hetao Rift; NNCB, Northern North China Basin; SNCB, Southern North China Basin.

Fig.2. (A) Tomographic maps of S-wave velocities of the NCC (modified from Jiang et al. (2013)). The dashed lines mark the primary tectonic boundaries and the dotted lines mark two Cenozoic rift zones. (B) Velocity gradient along profile A-A', B-B', C-C' as showing in (A).

Fig.3. (A) Map showing location of the Yilgarn craton and adjacent orogens. NA, Northen Australia; SA, Southern Australia. (B) Regional map of tectonic terranes in the Yilgarn craton (modified from Nemchin and Pidgeon (1997)). LTR (Lithospheric thinning region) represents the area that might have experienced SCLM thinning as indicated by geophysical data (Fig.4B; Fishwick and Reading (2008)). EGP, Eastern Goldfields superterrane; BJ, Buljah lamprophyres; JK, Jewill kimberlites; NC, Northampton complex; MC Mullingarra complex; LC, leeuwin Complex.

Fig.4. (A) Tomographic maps of S-wave velocities of the Yilgarn craton (modified from Fishwick and Reading (2008)). (B) Cross sections (blue line in (A)) showing the SCLM thinning area, dotted lines show the area that may experience SCLM thinning. Abbreviations used: Y, Yilgarn craton; C, Capricorn orogeny; P, Pilbara craton.

Fig.5. (A) Map showing location of the Superior and adjacent orogens. (B) Regional map of tectonic terranes in the Superior craton modified after Williams (1990), with kimberlite localities indicated. Abbreviations used: AC, Ashuanipi complex; AT, Abitibi terrane; BRT, Berens River terrane; BS, Bienville subprovince; DH, Douglas Harbour domain; ERT, English River terrane; EwT, East Wabigoon terrane; GD, Goudalie domain; ID, Inukjuak domain; KSZ, Kapuskasing Structural Zone; LG, La Grande subprovince; LM, Lake Minto domain; MRT, Minnesota River Valley terrane; ML, Munro Lake subprovince; NCT, North Caribou terrane; NSS, Northern Superior superterrane; PT, Pikwitonei terrane; QT, Quetico terrane; UD, Utsalik domain; WRT, Winnipeg River terrane;WT, Wawa terrane; WwT, West Wabigoon terrane. Numbers in rectangles are age information recorded by xenoliths, data source: Queen et al. (1996); Moser and Heaman (1997); Heaman et al. (2004); Sage (2000); Kaminsky et al. (2002).

Fig.6. Tomographic maps of S-wave velocities for depth from 100-250 km (modified from Frederiksen et al. (2007)). Green lines are boundaries of the Superior craton. The blue dotted line represents the interpreted boundary of lithosphere between western and eastern Superior craton. The red dotted lines are the Mid-continent rift. The yellow dotted line is a linear low-velocity anomaly related to the Great Meteor hot spot. FBR, failed branch of rift; MCR, Mid-continent rift. 
Table 1. Summary of major post-cratonization geologic events in the North China craton, as described in detail in the text.

\begin{tabular}{|c|c|c|c|c|}
\hline Time & Event & Subduction Polarity & Signature in SCLM & References \\
\hline$\sim 1.9-1.85 \mathrm{Ga}$ & Final amalgamation of NCC & & Replacement of part of root? & $\begin{array}{l}\text { Kusky and Li } 2003 \\
\text { Wilde et al. } 2002\end{array}$ \\
\hline$\sim 1.8 \mathrm{Ga}$ & Post-collision extension & & Mantle melting & $\begin{array}{l}\text { Li et al. } 2004 \\
\text { Kusky et al. 2007a }\end{array}$ \\
\hline$\sim 700-250 \mathrm{Ma}$ & Subduction from Dabie Shan & Toward the NCC & Hydration due to ingress of slab fluids? & $\begin{array}{l}\text { Hacker et al. } 2009 \\
\text { Kusky et al. 2007a }\end{array}$ \\
\hline$\sim 500-250 \mathrm{Ma}$ & Subduction from Solonker & Toward the NCC & Hydration due to ingress of slab fluids? & $\begin{array}{l}\text { Davis et al. } 1996 \\
\text { Xiao et al. 2003, } 2012\end{array}$ \\
\hline$\sim 270-208 \mathrm{Ma}$ & Indosinian orogeny & & Shortening of N edge of SCLM & Kusky et al. 2007a \\
\hline$\sim 200-100 \mathrm{Ma}$ & Subduction under Pacific margin & Toward the NCC & Hydration due to ingress of slab fluids? & $\begin{array}{l}\text { Zheng et al. } 2009 \\
\text { Kusky et al. } 2014\end{array}$ \\
\hline$\sim 50-0 \mathrm{Ma}$ & Himalayan orogeny & & Extrusion & Yin and Harrison 1996 \\
\hline
\end{tabular}


Table 2. Summary of major post-cratonization geologic events in the Yilgarn craton, as described in detail in the text.

\begin{tabular}{|l|l|l|l|}
\hline \multicolumn{1}{|c|}{ Time } & \multicolumn{1}{|c|}{ Event } & \multicolumn{1}{c|}{ Subduction Polarity } & \multicolumn{1}{c|}{ References } \\
\hline$\sim 2.7-2.5 \mathrm{Ga}$ & Final assembly of the Yilgarn craton & & Huston et al. 2012; Myers 1993 \\
\hline$\sim 2.2-1.8 \mathrm{Ga}$ & Capricorn orogeny & Toward the Yilgarn craton & Cawood and Tyler 2004 \\
\hline$\sim 1.79-1.78 \mathrm{Ga}$ & Yapungku orogeny & Away from the Yilgarn craton & Bagas 2004; Giles et al. 2004 \\
\hline$\sim 1.3-1.0 \mathrm{Ga}$ & Albany-Fraser orogeny & Away from the Yilgarn craton & Myers et al. 1996; Smithies et al. 2010 \\
\hline$\sim 1.21 \mathrm{Ga}$ & Marnda Moorn igneous event & & Wang et al. 2013 \\
\hline$\sim 522 \mathrm{Ma}$ & Pinarra orogeny & Away from the Yilgarn craton & Collins 2003; Collins and Pisarevsky 2005 \\
\hline$\sim 120 \mathrm{Ma}$ & Separated From Great Indian & & Norvick and Smith 2001; Veevers 2006 \\
\hline
\end{tabular}


Table 3. Summary of major post-cratonization geologic events in the Superior craton, as described in detail in the text.

\begin{tabular}{|c|l|l|l|}
\hline Time & \multicolumn{1}{|c|}{ Event } & Subduction polarity & Reference \\
\hline$\sim 3.0-2.6 \mathrm{Ga}$ & Assembly of the Superior craton & & Card and Poulsen 1998; Percival et al. 2006 \\
\hline$\sim 2.8-2.6 \mathrm{Ga}$ & Kenoran orogeny & Away from the Superior craton & Percival et al. 2006; Thurston 1991 \\
\hline$\sim 2.5-2.0 \mathrm{Ga}$ & Sedimentary basins spanning & & Buchan and Ernst 2004 \\
\hline$\sim 2.0 \mathrm{Ga}$ & Tectonic regime change & & Hoffman 1988; Ernst et al. 1995, 2014 \\
\hline$\sim 1.9-1.6 \mathrm{Ga}$ & Penokean orogeny & Away from the Superior craton & Schultz and Cannon 2007 \\
\hline$\sim 1.8 \mathrm{Ga}$ & Trans-Hudson orogeny & & Eaton and Darbyshire 2010 \\
\hline$\sim 1.1 \mathrm{Ga}$ & Keweenawan Mid-continent rift & & Thurston et al. 1991 \\
\hline$\sim 1.3-1.0 \mathrm{Ga}$ & Grenville orogeny & Away from the Superior craton & Hoffman 1989; Tohver et al. 2005 \\
\hline$\sim 180-134 \mathrm{Ma}$ & $\begin{array}{l}\text { Emplacement of kimberlite along } \\
\text { track of Great Meteor hotspot }\end{array}$ & & $\begin{array}{l}\text { Heaman and Kjarsgaard 2000; } \\
\text { Heaman et al. 2004 }\end{array}$ \\
\hline
\end{tabular}




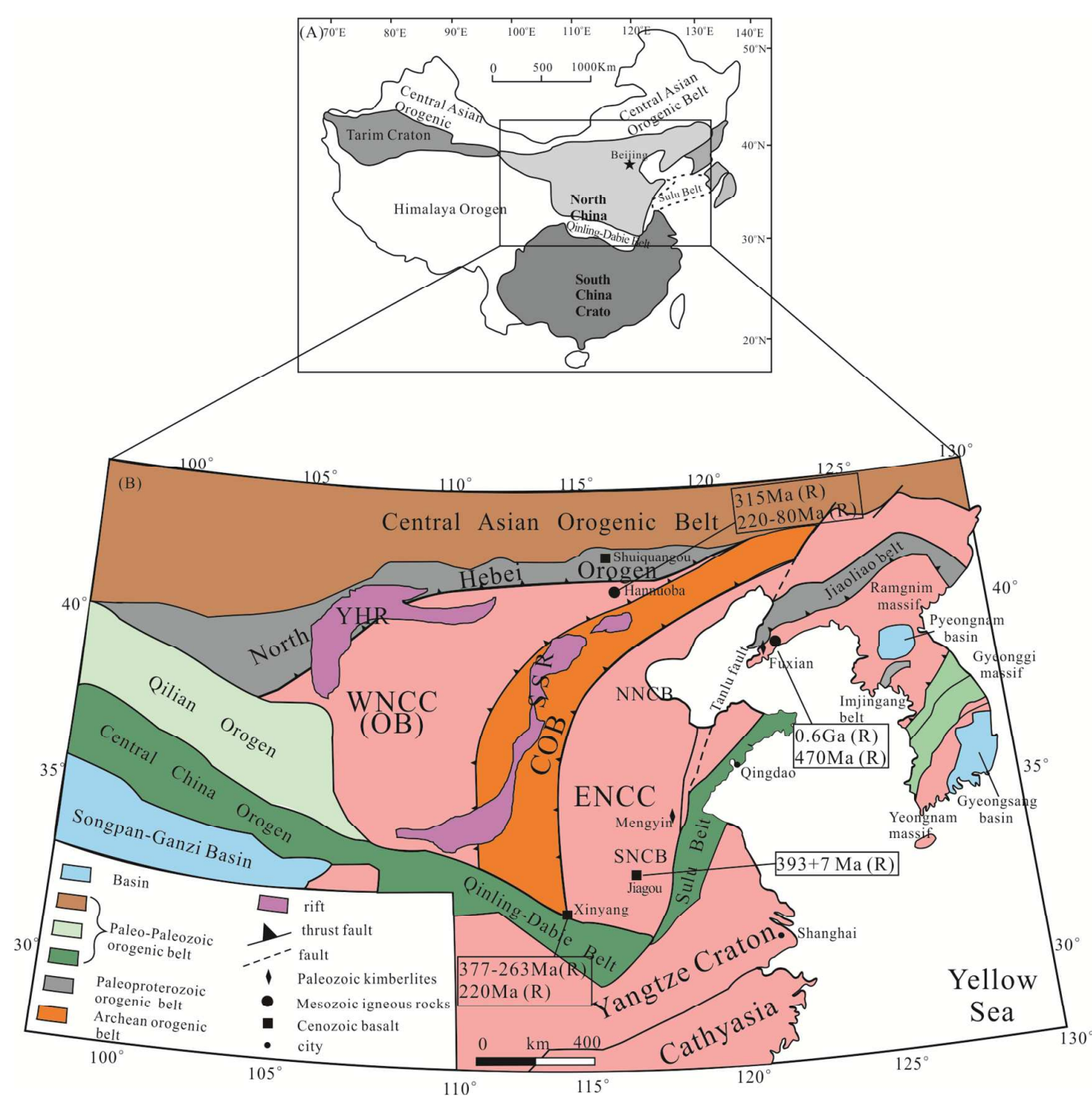

Fig.1. (A) Schematic geological map of NCC and adjacent areas. (B) Simplified tectonic map of NCC (modified from Kusky et al. (2014a)). Numbers in rectangles are age information recorded by xenoliths (only presented data related with marginal lithospheric thinning), R means reworking. Xenoliths Data source: Zheng et al. 2004, 2005, 2012; Zheng and Wu 2009; Yu et al. 2007; Zhang et al. 2012; Liu et al. 2013. WNCC: Western part of the North China Craton (also known as the Ordos Block, e.g., OB); ENCC: Eastern part of the North China Craton; COB: Central Orogenic Belt; SSR, Shanxi-Shaanxi Rift; YHR, Yinchuan-Hetao Rift; NNCB, Northern North China Basin; SNCB, Southern North China Basin. 
(A)
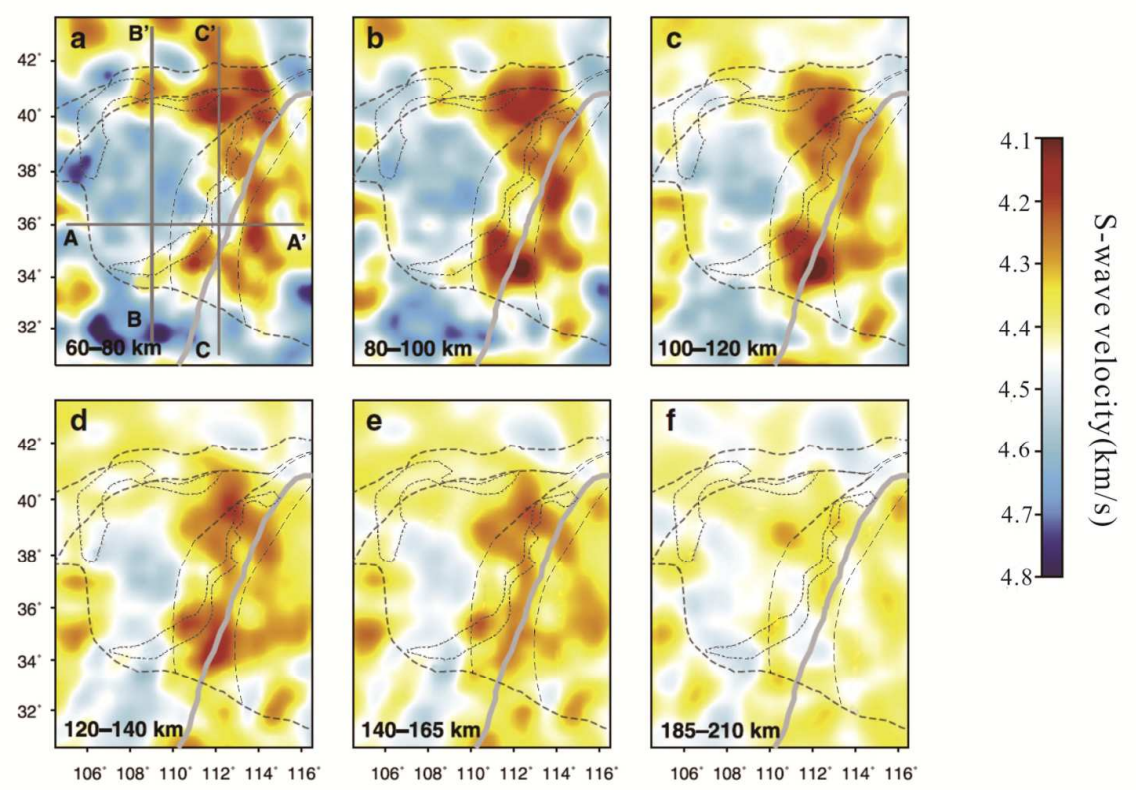

(B)
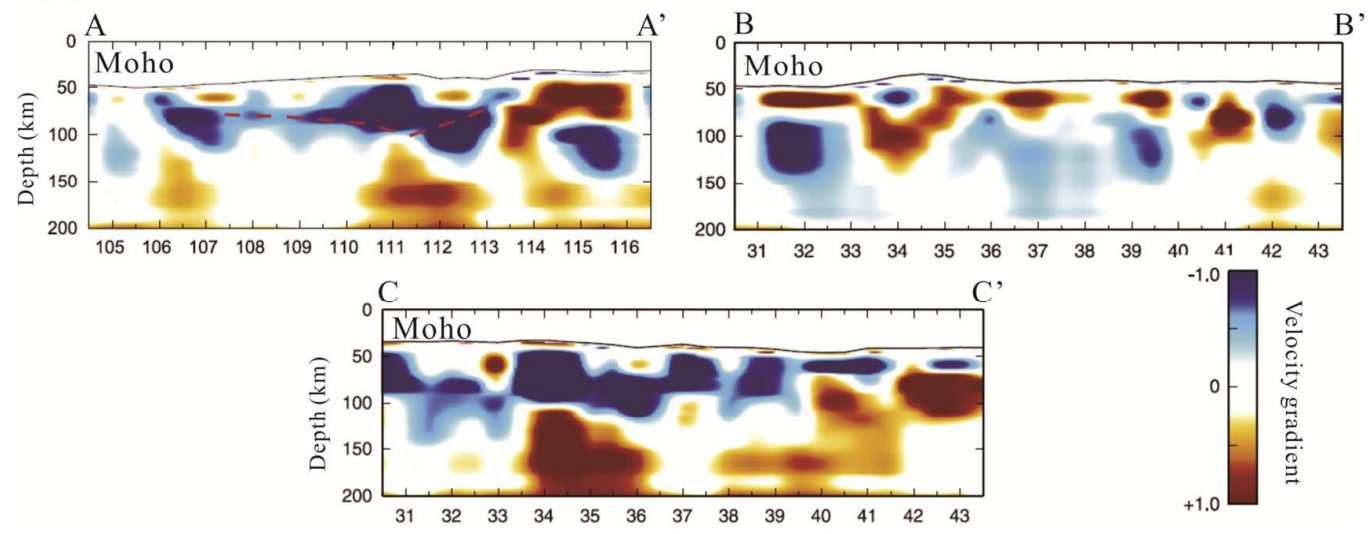

Fig.2. (A) Tomographic maps of S-wave velocities of the NCC (modified from Jiang et al. (2013)). The dashed lines mark the primary tectonic boundaries and the dotted lines mark two Cenozoic rift zones. (B) Velocity gradient along profile A-A', B-B', C-C' as showing in (A). 


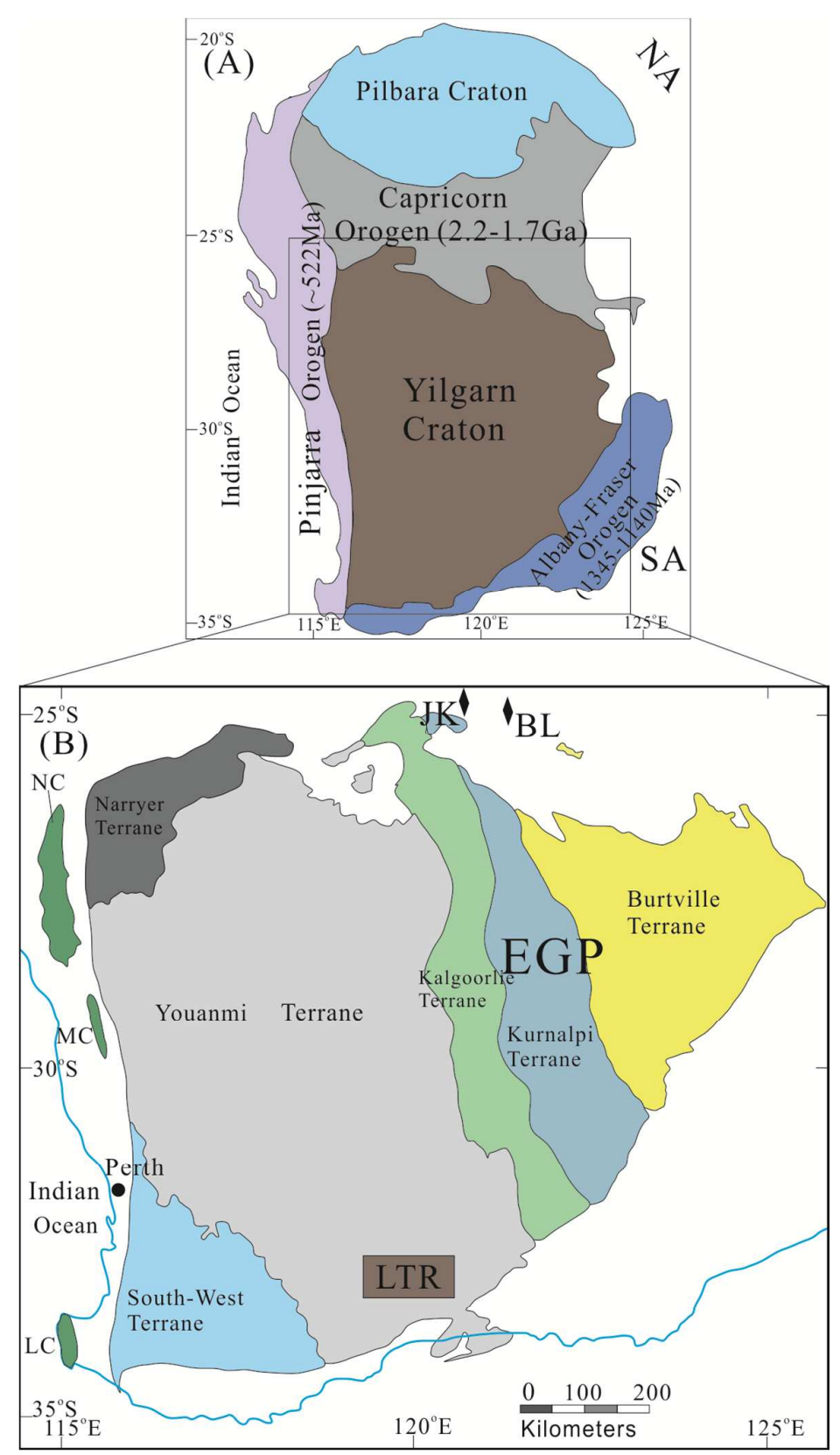

Fig.3. (A) Map showing location of the Yilgarn craton and adjacent orogens. NA, Northen Australia; SA, Southern Australia. (B) Regional map of tectonic terranes in the Yilgarn craton (modified from Nemchin and Pidgeon (1997)). LTR (Lithospheric thinning region) represents the area that might have experienced SCLM thinning as indicated by geophysical data (Fig.4B; Fishwick and Reading (2008)). EGP, Eastern Goldfields superterrane; BJ, Buljah lamprophyres; JK, Jewill kimberlites; NC, Northampton complex; MC Mullingarra complex; LC, leeuwin Complex. 


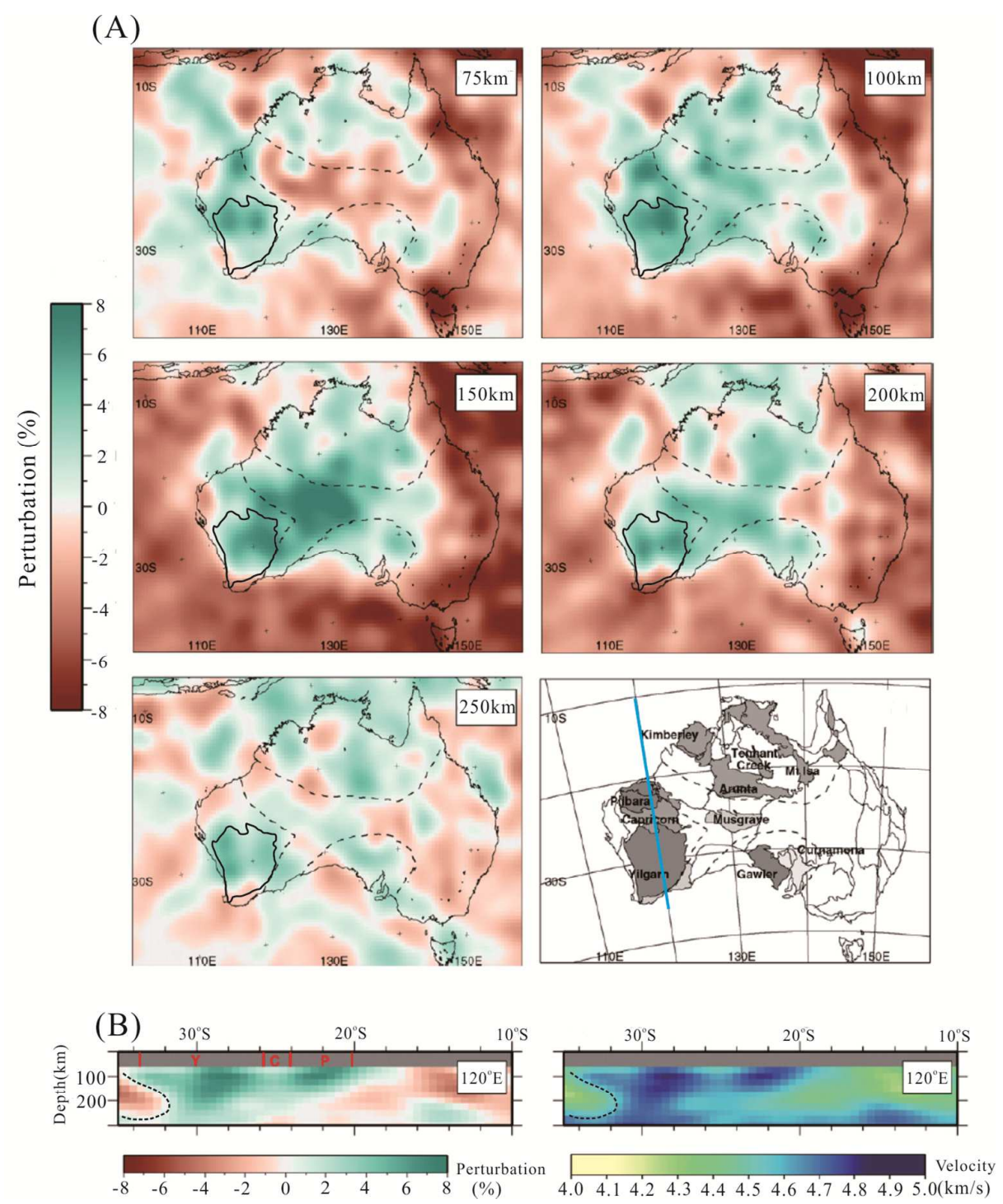

Fig.4. (A) Tomographic maps of S-wave velocities of the Yilgarn craton (modified from Fishwick and Reading (2008)). (B) Cross sections (blue line in (A)) showing the SCLM thinning area, dotted lines show the area that may experience SCLM thinning. Abbreviations used: Y, Yilgarn craton; C, Capricorn orogeny; P, Pilbara craton. 


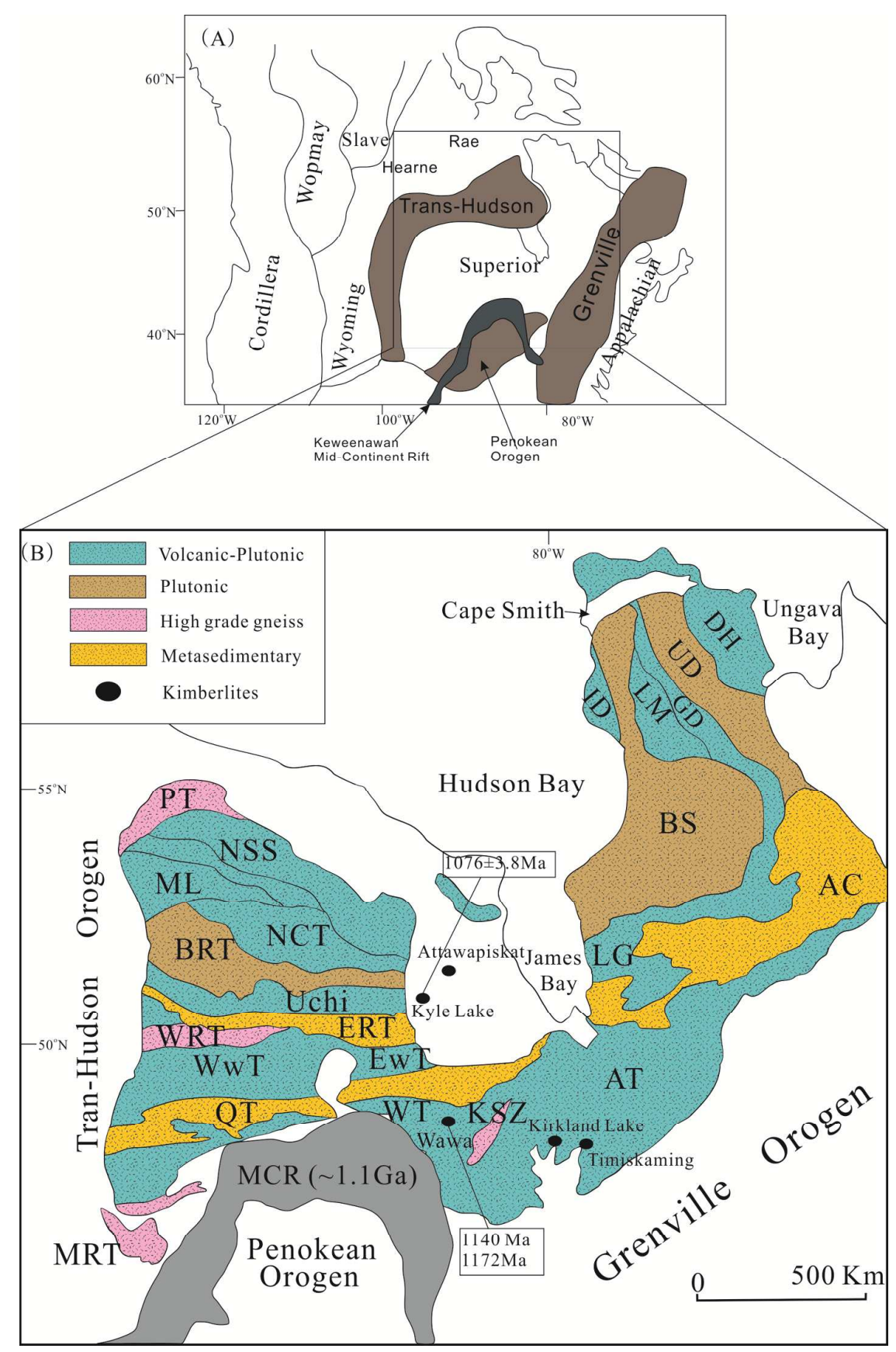

Fig.5. (A) Map showing location of the Superior and adjacent orogens. (B) Regional map of tectonic terranes in the Superior craton modified after Williams (1990), with kimberlite localities indicated. Abbreviations used: AC, Ashuanipi complex; AT, Abitibi terrane; BRT, Berens River terrane; BS, Bienville subprovince; DH, Douglas Harbour domain; ERT, English River terrane; EwT, East Wabigoon terrane; GD, Goudalie domain; ID, Inukjuak domain; KSZ, Kapuskasing Structural Zone; LG, La Grande subprovince; LM, Lake Minto domain; MRT, Minnesota River Valley terrane; ML, Munro Lake subprovince; NCT, North Caribou terrane; NSS, Northern Superior superterrane; PT, Pikwitonei terrane; QT, Quetico terrane; UD, Utsalik domain; WRT, Winnipeg River terrane;WT, Wawa terrane; WwT, West Wabigoon terrane. Numbers in rectangles are age information recorded by xenoliths, data source: Queen et al. (1996); Moser and Heaman (1997); Heaman et al. (2004); Sage (2000); Kaminsky et al. (2002). 

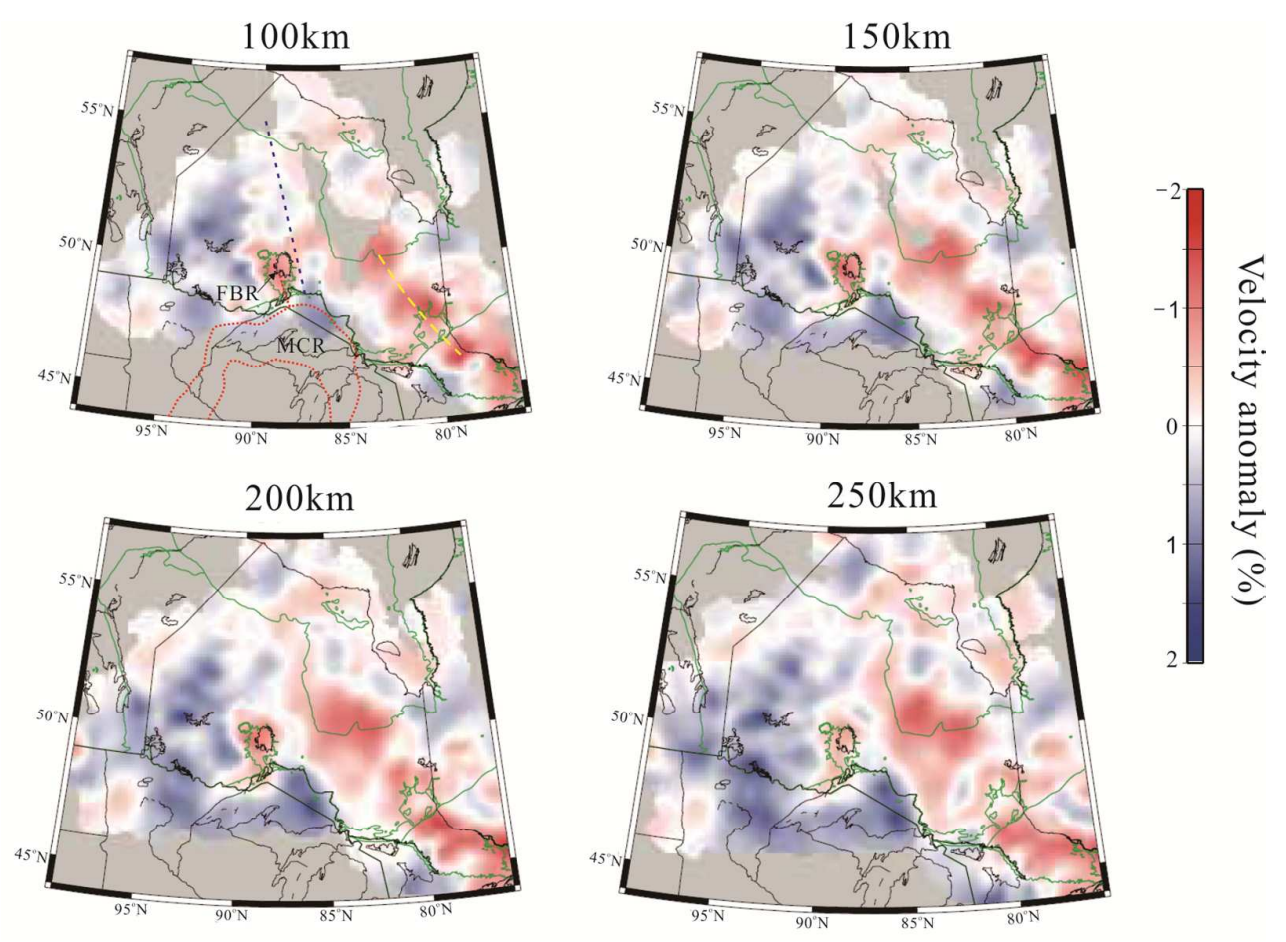

Fig.6. Tomographic maps of S-wave velocities for depth from 100-250 km (modified from Frederiksen et al. (2007)). Green lines are boundaries of the Superior craton. The blue dotted line represents the interpreted boundary of lithosphere between western and eastern Superior craton. The red dotted lines are the Mid-continent rift. The yellow dotted line is a linear low-velocity anomaly related to the Great Meteor hot spot. FBR, failed branch of rift; MCR, Mid-continent rift. 